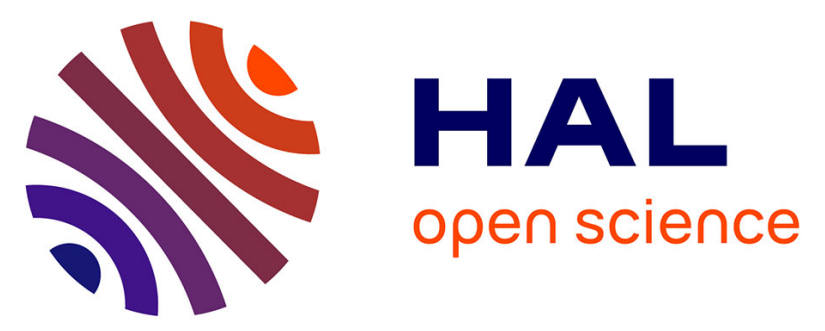

\title{
Experimental silicification of the extremophilic Archaea Pyrococcus abyssi and Methanocaldococcus jannaschii: applications in the search for evidence of life in early Earth and extraterrestrial rocks
}

François Orange, Francès Westall, Jean-Robert Disnar, D. Prieur, N. Bienvenu, M. Le Romancer, Christian Défarge

\section{To cite this version:}

François Orange, Francès Westall, Jean-Robert Disnar, D. Prieur, N. Bienvenu, et al.. Experimental silicification of the extremophilic Archaea Pyrococcus abyssi and Methanocaldococcus jannaschii: applications in the search for evidence of life in early Earth and extraterrestrial rocks. Geobiology, 2009, 7 (4), pp.403-418. 10.1111/j.1472-4669.2009.00212.x . insu-00409631

HAL Id: insu-00409631

https://hal-insu.archives-ouvertes.fr/insu-00409631

Submitted on 10 Sep 2009

HAL is a multi-disciplinary open access archive for the deposit and dissemination of scientific research documents, whether they are published or not. The documents may come from teaching and research institutions in France or abroad, or from public or private research centers.
L'archive ouverte pluridisciplinaire HAL, est destinée au dépôt et à la diffusion de documents scientifiques de niveau recherche, publiés ou non, émanant des établissements d'enseignement et de recherche français ou étrangers, des laboratoires publics ou privés. 


\title{
Experimental silicification of the extremophilic Archaea Pyrococcus abyssi and Methanocaldococcus jannaschii: applications in the search for evidence of life in early Earth and extraterrestrial rocks
}

\author{
F. ORANGE ${ }^{1,2,3}$, F. WESTALL ${ }^{1,3}$, J.-R. DISNAR $^{2}$, D. PRIEUR $^{4}$, N. BIENVENU ${ }^{4}$, M. LE ROMANCER $^{4}$ \\ and CH. DÉFARGE ${ }^{2}$ \\ ${ }^{1}$ Centre de Biophysique Moléculaire, CNRS, Orléans cedex, France \\ ${ }^{2}$ Université d'Orléans, CNRS/INSU, Institut des Sciences de la Terre d'Orléans, Orléans cedex, France \\ ${ }^{3}$ Observatoire des Sciences de l'Univers en région Centre, Campus Géosciences, Orléans cedex, France \\ ${ }^{4}$ Université de Bretagne Occidentale, Institut Universitaire Européen de la Mer, Plouzané, France
}

\begin{abstract}
The early Earth was characterized by anoxic and apparently warm environmental conditions, strongly influenced by hydrothermal activity, with maximal sea-water temperatures of $<55^{\circ} \mathrm{C}$ (van den Boorn et al., 2007), although higher temperatures up to $80^{\circ} \mathrm{C}$ have also been proposed (Knauth \& Lowe, 2003; Robert \& Chaussidon, 2006). Strong hydrothermal influence is also seen in the massive silicification of both volcanic and sedimentary units in Early Archean (3.5-3.3 Ga) terrains in the Pilbara Craton, northwest Australia and the Barberton greenstone belt, South Africa (e.g. Orberger et al., 2006; Hofmann \& Bolhar, 2007). The warmer oceans were also probably slightly more acidic than today $(\mathrm{pH} 6$; Grotzinger \& Kasting, 1993) as a result of the high $\mathrm{CO}_{2}$ content in the atmosphere (oxygen levels were $<0.2 \%$ of present atmospheric levels; Kasting, 1993). The kinds of microorganisms living on the early Earth probably included a variety of species capable of inhabiting the different types of microenvironments that were present, including thermophilic and hyperthermophilic species in and around hot spring environments.
\end{abstract}

As a result of the high concentration of silica in the Early Archean oceans, fossil microorganisms in sediments from this epoch are, for the most part, preserved as silicified remnants (review in Westall \& Southam, 2006). Although there has been much debate regarding the biogenicity of many of the microfossil structures [e.g. Brasier et al. (2002) vs. Schopf (1993) and Schopf et al. (2002)], as well as their syngenicity [e.g. Westall \& Folk (2003) vs. Pflug \& Jaeschke-Boyer (1979)], recent multidisciplinary investigations have revealed morphological, geochemical and isotopic traces that clearly originate from micro-organisms living in and on the Early Archaean sediments. For instance, Westall et al. (2006a) documented silicified colonies of small $(<1 \mu \mathrm{m})$ coccoidal micro-organisms associated with 3.466 Ga-old volcanic sands and silts deposited in an intertidal setting from the Pilbara Craton in Australia (Fig. 1). From similar-aged sediments $(3.33 \mathrm{Ga})$ in the Barberton greenstone belt, a thin but robust microbial mat formed by $0.25-\mu \mathrm{m}$ diameter filaments was silicified on the top of volcanic littoral silts (Westall et al., 2006b). Walsh $(1992,2004)$ and Tice \& Lowe $(2004,2007)$ also documented silicified microbial mat remnants in the Barberton cherts. At a larger scale in the Pilbara Craton, Allwood et al. (2006, 2009) mapped fields of small, silicified stromatolites exhibiting different morphologies related to subtle changes in their shallow water carbonate platform environment.

Little is known about the microbial composition of the original communities to which the Early Archaean silicified micro-organisms belonged, although the occurrence of microfossils having different morphologies and sizes within the same colony (e.g. Westall et al., 2006a) 
suggests that different species may be involved. What proportion of the original microbial diversity is represented by the fossil remains in the cherts?

There are two approaches to this problem, studying microfossils in recent silicifying hydrothermal environments and experimentally silicifying thermophilic-hyperthermophilic micro-organisms. Studies of recent silicifying environments, such as hot spring habitats relevant to the Early Archaean period (and early Mars), provide a certain amount of information, although modern environments are aerobic in contrast to early terrestrial or Martian ones. In situ silicification was thus studied in numerous hydrothermal systems, such as in Yellowstone (Walter et al., 1972; Cady \& Farmer, 1996), Iceland (Schultze-Lam et al., 1995; Konhauser \& Ferris, 1996; Konhauser et al., 2001) or New-Zealand (Jones et al., 1998, 2001, 2003, 2004; Handley et al., 2005, 2008). Most of these studies describe the result of the complete fossilization of the micro-organisms and their extracellular polymeric substances (EPS), where important amounts of silica have faithfully preserved microbial shapes over several years although no organic matter remains. Only a few studies (e.g. Schultze-Lam et al., 1995; Phoenix et al., 2000) described the early steps of the silicification with living micro-organisms exposed to a silica-saturated environment.

The second method, the experimental fossilization of micro-organisms, is the approach we have taken. We silicified two strains of strictly anaerobic and hyperthermophilic microorganisms that could have lived in hydrothermal environments on the early Earth (and possibly early Mars), Methanocaldococcus jannaschii (Jones et al., 1983) and Pyrococcus abyssi (Erauso et al., 1993).

Early microbial fossilization experiments (Oehler \& Schopf, 1971; Oehler, 1976; Francis et al., 1978) concentrated mostly on the silicification of cyanobacteria, as these were considered to be the most common ancient microfossils. Cyanobacteria are now believed to have evolved later in geological history (Westall \& Southam, 2006; Rasmussen et al., 2008). In subsequent experiments, other types of micro-organisms experimentally silicified included the Gram-positive bacterium Bacillus subtilis (Ferris et al., 1988), a spirochete (Francis et al., 1978), the Bacterium Desulfovibrio desulfuricans (Birnbaum et al., 1989), a variety of marine micro-organisms (Westall et al., 1995), the Gram-negative bacteria Pseudomonas vesicularis, Pseudomonas acidovorans and Pseudomonas fluorescens and the Gram-positive bacterium Bacillus laterosporus (Westall, 1997), the Bacteria Desulfovibrio indonensis and $P$. fluorescens (Toporski et al., 2002), the cyanobacteria Calothrix sp. (Benning et al., 2004a,b), and chemolithotrophic and thermophilic Bacteria Sulfurihydrogenibium azorense (Lalonde et al., 2005). These studies showed that different kinds of micro-organisms can be preserved by silicification, with good preservation of cellular structures. None of the previous investigations was made on micro-organisms from the Archaea Domain and only one concerned thermophiles (Lalonde et al., 2005). This lack of knowledge of the fossilization of hyperthermophilic or thermophilic prokaryotes contrasts with the growing interest in them as possible analogues of the earliest life forms.

\section{Material and methods}

\section{Pyrococcus abyssi and Methanocaldococcus jannaschii}

The strains P. abyssi (Erauso et al., 1993) and M. jannaschii (Jones et al., 1983) were chosen because they are well-studied hyperthermophilic and strictly anaerobic members of the Archaea Domain, and, as such, good analogues for prokaryotes that could have lived on the Early Archean Earth. 
Pyrococcus abyssi was isolated from a deep-sea hydrothermal vent from the North Fiji Basin. It is a hyperthermophilic, sulphur-metabolizing strict anaerobe and strict chemoorganotroph that can grow between 67 and $102{ }^{\circ} \mathrm{C}$ (optimum $96{ }^{\circ} \mathrm{C}$ ) and at $\mathrm{pH}$ values between 4.0 and 8.0 (optimum 7.0) (Erauso et al., 1993). Methanocaldococcus jannaschii was also isolated from a hydrothermal vent on the East Pacific Rise (Jones et al., 1983). This hyperthermophilic, methanogenic, strict aerobe and facultative autotroph can grow between 45 and $86^{\circ} \mathrm{C}$ (optimum $80^{\circ} \mathrm{C}$ ) and at a pH value between 5.2 and 7.0 (optimum 6.0). Methanocaldococcus jannaschii cells are osmotically very fragile.

Species in the Archaea Domain are distinguished from those in the Bacteria Domain primarily on the basis of the composition of their cell envelopes. While the bacterial membrane is made of diacyl-D-glycerol diesters, the archaeal membrane consists of isoprenoid L-glycerol diethers or di-L-glycerol tetraethers (Kandler \& König, 1998), with long isoprenoid chains containing 20-40 carbon atoms. The majority of Archaea, including P. abyssi and $M$. jannaschii, possesses a simple cell-wall structure with only a plasmic membrane and a surface layer (S-layer) made of proteins and glycoproteins, forming a paracrystallin structure (Jones et al., 1983; Erauso et al., 1993; Forterre et al., 2002; König, 2002).

\section{Cell growth}

Pure cultures of $M$. janaschii and $P$. abyssi were provided by the Laboratoire de Microbiologie des Environnements Extrêmes (Brest, France). Pyrococcus abyssi (strain GE5) was cultured in the medium described by Geslin et al. (2003), with slight modifications. The medium contained (per litre of distilled water) $1 \mathrm{~g}$ of $\mathrm{NH}_{4} \mathrm{Cl}, 0.2 \mathrm{~g}$ of $\mathrm{MgCl}_{2} \cdot 6 \mathrm{H}_{2} \mathrm{O}, 0.1 \mathrm{~g}$ of $\mathrm{CaCl}_{2} \cdot 2 \mathrm{H}_{2} \mathrm{O}, 0.1 \mathrm{~g}$ of $\mathrm{KCl}, 0.83 \mathrm{~g}$ of $\mathrm{CH}_{3} \mathrm{COONa} \cdot 3 \mathrm{H}_{2} \mathrm{O}, 5 \mathrm{~g}$ of yeast extract, $5 \mathrm{~g}$ of bioTrypcase, $20 \mathrm{~g}$ of $\mathrm{NaCl}, 3.45 \mathrm{~g}$ of piperazine-N,N'-bis(2-ethanesulfonic acid) (PIPES) and $0.001 \mathrm{~g}$ of resazurin. The $\mathrm{pH}$ was adjusted to 7 and the medium was sterilized by autoclaving. Five millilitres of a $6 \%(\mathrm{wt} / \mathrm{vol}) \mathrm{KH}_{2} \mathrm{PO}_{4}$ solution and $5 \mathrm{~mL}$ of a $6 \%$ (wt/vol) $\mathrm{K}_{2} \mathrm{HPO}_{4}$ solution were added. Twenty millilitres of the medium were dispensed into $50-\mathrm{mL}$ sterile vials to which $0.2 \mathrm{~g}$ of previously sterilized elemental sulphur was added. Anaerobiosis was obtained by applying vacuum to the vial and saturating it with $\mathrm{N}_{2}$ (Balch \& Wolfe, 1976). Finally, the medium was reduced by adding $0.2 \mathrm{~mL}$ of a sterile $10 \%$ (wt/vol) solution of $\mathrm{Na}_{2} \mathrm{~S} \cdot 9 \mathrm{H}_{2} \mathrm{O}$ to each vial. The medium was inoculated to a final concentration of $3 \%$ and incubated at $90{ }^{\circ} \mathrm{C}$ with shaking. Microbial growth was monitored by a phase-contrast microscope (Olympus CX 40). The end of the exponential growth phase was usually obtained after $24 \mathrm{~h}$. Methanocaldococcus jannaschii was cultured in a 'poor' autotrophic medium. The medium contained (per litre of distilled water) $25 \mathrm{~g}$ of $\mathrm{NaCl}, 3 \mathrm{~g}$ of $\mathrm{MgCl}_{2}, 1 \mathrm{~g}$ of $\mathrm{NH}_{4} \mathrm{Cl}$, $0.15 \mathrm{~g}$ of $\mathrm{CaCl}_{2}, 0.5 \mathrm{~g}$ of $\mathrm{KCl}, 0.3 \mathrm{~g}$ of $\mathrm{KH}_{2} \mathrm{PO}_{4}$ and $0.001 \mathrm{~g}$ of resazurin. The $\mathrm{pH}$ was adjusted to 6.5 and the medium was sterilized by autoclaving. Twenty millilitres of the medium were dispensed into $50-\mathrm{mL}$ sterile vials. Anaerobiosis were obtained by first applying vacuum to the vial and then saturating it with $\mathrm{N}_{2}$ (Balch \& Wolfe, 1976), which was then replaced by a $\mathrm{H}_{2} / \mathrm{CO}_{2}$ atmosphere $(80: 20 ; 300 \mathrm{kPa})$. The medium was finally reduced by adding $0.2 \mathrm{~mL}$ of a sterile $10 \%$ (wt/vol) solution of $\mathrm{Na}_{2} \mathrm{~S} \cdot 9 \mathrm{H}_{2} \mathrm{O}$ to each vial. The medium, inoculated to a final concentration of $1 \%$, was incubated at $80{ }^{\circ} \mathrm{C}$ with shaking. Microbial growth was monitored by a phase-contrast microscope (Olympus CX 40). The end of the exponential growth phase was usually obtained after $24-36 \mathrm{~h}$. Continued growth resulted in a rapid decrease in cell number due to lysis. At the end of the exponential phase, the cell concentrations in the two cultures were therefore different, given that M. Janaschii had been cultured in a 'poorer' medium than P. abyssi. Cell densities in the P. abyssi culture were far 
higher than those in the $M$. jannaschii culture, the culture medium in the former case being completely opaque whereas the medium in the second case was clear.

\section{Silicification procedure}

In our experiment, the micro-organisms were directly fossilized in their culture medium to have cells that were still alive with available nutrients at the beginning of silicification, thus imitating a situation in which micro-organisms are caught in a concentrated flow of silica, for example from a hydrothermal outflow. Furthermore, as in the natural environment, the culture medium contains mineral elements that can interact with silica and influence the silicification process. Urrutia \& Beveridge (1994), for example, found that interstratified clay formed in some silicification experiments. Another reason for silicifying directly in the culture medium is that some micro-organisms, e.g. M. jannaschii, secrete EPS in the culture medium, which allowed us to study the fossilization of cells and EPS separately.

The silicification procedure used in this study was adapted from that used in previous experimental silicifications (Oehler \& Schopf, 1971; Oehler, 1976; Francis et al., 1978; Ferris et al., 1988; Birnbaum et al., 1989; Westall et al., 1995; Westall, 1997; Toporski et al., 2002; Benning et al., 2004a,b). To simulate more closely silica dissolved in seawater, we followed the procedure of Birnbaum et al. (1989), Toporski et al. (2002), Yee et al. (2003) and Benning et al. (2004a,b) who used a sodium silicate solution rather than the organo-silicate solution, Tetramethylorthosilane (TEOS), used by Oehler \& Schopf (1971), Oehler (1976), Francis et al. (1978), Westall et al. (1995) and Westall (1997). In an additional improvement to the silicification methodology, we used silica concentrations $(500 \mathrm{ppm})$ that are closer to those found in nature in hydrothermal environments (Schultze-Lam et al., 1995; Jones et al., 2003; Mountain et al., 2003), whereas Toporski et al. (2002) used concentrations up to $5000 \mathrm{ppm}$.

Silicification was launched at the end of the exponential growth phase, reached after $12 \mathrm{~h}$ for P. abyssi, and 1-2 days for M. jannaschii. For each strain, a small amount of the fresh culture was collected and fixed in $2.5 \%$ glutaraldehyde and stored at $4{ }^{\circ} \mathrm{C}$ until preparation. As a silicifying agent, we used a commercially available pure sodium silicate solution (Riedel de Haën) containing $\sim 27 \% \mathrm{SiO}_{2}$ and $\sim 10 \% \mathrm{NaOH}\left(\mathrm{Na}_{2} \mathrm{Si}_{3} \mathrm{O}_{7}, M=242 \mathrm{~g} \mathrm{~mol}^{-1}\right)$. This pure solution was diluted 10 times to make a stock solution and filtered at $0.2 \mu \mathrm{m}$ for sterilization and to remove any particulate material. $0.4 \mathrm{~mL}$ of this stock solution were injected into each vial to obtain a final approximate silica concentration of $500 \mathrm{ppm}$. The injection of silica into the microbial cultures marked the 'time zero' of the silicification. Separate vials were prepared for silicification times of $24 \mathrm{~h}$ to 1 year. Control samples consisting of the culture medium without micro-organisms were prepared in a similar way.

After the silica injection, each vial was placed in an oven at $60^{\circ} \mathrm{C}$ until sampled. This temperature was chosen to match the estimated temperature of early Earth oceans. The control samples (no cells inoculated) were left in the oven for 1 month. After their respective fossilization times (different for each vial), a small amount of the mixture ( $2 \mathrm{~mL}$ for P. abyssi, $20 \mathrm{~mL}$ for $M$. jannaschii) was collected with a syringe and filtered on a $0.2-\mu \mathrm{m}$ Millipore filter. This filter was then placed in a $2.5 \%$ glutaraldehyde solution and stored at $4{ }^{\circ} \mathrm{C}$ until needed. 
We noted during the experiment that $M$. jannaschii, an osmotically fragile strain, had a propensity to lyse and further tests were run to control the effects of silica injection and $\mathrm{pH}$ change on growth or lysis rate. Cells counts were performed by optical microscopy before and $24 \mathrm{~h}$ after the $M$. jannaschii cells had been subjected to the following medium changes: (i) injection of $0.4 \mathrm{~mL}$ of the sodium silicate solution to obtain $\left[\mathrm{SiO}_{2}\right]=500 \mathrm{ppm}$ (identical to the silicification procedure); (ii) injection of $0.4 \mathrm{~mL}$ of the sodium silicate solution to obtain $\left[\mathrm{SiO}_{2}\right]=500 \mathrm{ppm}, \mathrm{pH}$ adjusted with $\mathrm{HCl}$ to the initial medium value $(\sim 6.5)$; and (iii) $\mathrm{pH}$ increased to $\sim 7.8$ with $\mathrm{NaOH}$ to reproduce the $\mathrm{pH}$ change induced by the injection of the sodium silicate solution. Tests were made during both the growth phase and the lysis phase (prolonged growth). Control experiments, without medium changes, were also made.

\section{Preparation for scanning and transmission electron microscopy analysis}

Samples for scanning electron microscopy (SEM) analysis were washed four times for $15 \mathrm{~min}$ in a $\mathrm{pH} 7.4$ sodium phosphate buffer, while being gently shaken. The samples were then filtered on a $0.2-\mu \mathrm{m}$ filter that was placed into microporous ceramic specimen capsules for critical-point drying. They were then dehydrated using a series of increasing ethanol/distilled water solutions, with percentage steps of $10,30,50,70$ and 93 , and finally three times in absolute ethanol (15 min for each step). This was followed by an ethanol/acetone series (10\%, $30 \%, 50 \%, 70 \%, 90 \%$ and finally three times in 100\% acetone, $15 \mathrm{~min}$ for each step). Samples were then dried with the critical-point method. The dried samples were gold coated prior to the observation and analysis with a Hitachi S4500 Field Emission Gun Scanning Electron Microscope, equipped with a EDX detector (Oxford Instruments).

Samples for transmission electron microscopy (TEM) analysis were rinsed four times for 15 min in a pH 7.4 sodium phosphate buffer, while being gently shaken. The samples were then filtered on a $0.2-\mu \mathrm{m}$ filter that was cut into small millimetre-sized squares that were embedded in a $20-\mathrm{g} \mathrm{L}^{-1}$ agar-agar solution. After the agar-agar cooled and hardened, the sample was dehydrated using a series of increasing ethanol/distilled water solutions in percentage steps of $10,30,50,70$ and 93 , and finally three times in absolute ethanol (15 min for each step), followed by an ethanol/acetone series $(10 \%, 30 \%, 50 \%, 70 \%, 90 \%$ and finally three times in $100 \%$ acetone, $15 \mathrm{~min}$ for each step). The samples were prepared for ultrathin sectioning by embedding in TAAB 812 Resin (TAAB Laboratories, UK), with a series of acetone/resin mixtures in the proportions $3: 1,1: 1$ and $3: 1$, followed by two baths in $100 \%$ resin ( $3 \mathrm{~h}$ for each step). The resin blocs were finally left to harden in a $60{ }^{\circ} \mathrm{C}$ oven for 3 days. Ultrathin sections were made using a Diatome diamond knife mounted on a Reichert ultramicrotome and placed on carbon-coated copper TEM grids. To increase contrast, some grids were treated with stains: they were placed on drops of a $4-\mathrm{g} \mathrm{L}^{-1}$ lead citrate solution for $7 \mathrm{~min}$ and then for $20 \mathrm{~min}$ on drops of a saturated uranyl acetate saturated solution prepared in $50 \%$ ethanol. Some grids were also observed unstained to establish evidence of silica deposition on cellular structures. Observations and analysis were made with a Philips CM20 Transmission Electron Microscope, equipped with an EDX detector (Oxford Instruments).

\section{Results}

\section{Pyrococcus abyssi silicification experiment}

Pyrococcus abyssi cells are regular 1- $\mu \mathrm{m}$ diameter coccoids that are often seen in division (Fig. 2a; Erauso et al., 1993). At the end of growth, the cell density was very high, leading to a clouded appearance in the culture medium. Living cells were still observable by optical microscopy after 1 month of exposure to silica. This was confirmed by inoculating a few 
millilitres of this sample in a fresh culture medium. Normal growth occurred and the end of the exponential growth phase was reached after 1 day. Several observations with optical microscopy suggested that this was the case for up to several months of silicification. Following the injection of the silica solution, the $\mathrm{pH}$ in the medium increased slightly, from 7.0 to 7.5 , but did not change afterwards

Already after $24 \mathrm{~h}$ of silicification, light microscopy showed that a noticeable precipitate of granular amorphous silica (opal-A) was formed that embedded many cells. Aggregates of cells also formed as a result of centrifugation of the samples in preparation for electron microscopy, leading to the formation of 'frog-egg' like cells aggregates (Fig. 2b,c). This deposit has an electron dense signature in the TEM micrographs (Fig. 2e). Over the year that the experiment continued, the amorphous silica precipitate became more dense, embedding most cells (Fig. 3b,d,e), with an increase in the size of the silica particles (from 10 to

$20 \mathrm{~nm}$ ). The cells initially had a perfect coccoidal shape but became increasingly deformed with time (Fig. 3a,c), although the degree of deformation was variable between cells. Morphological deformation was manifested by the disappearance of the cell-wall structure as the amorphous silica precipitate became more dense (Fig. 4), an increase in the wrinkling of the cell surfaces and contortion of the cells trapped within the mineral matrix (Fig. 3d), and lysis and loss of the cytoplasmic material (Fig. 3g).

At the end of the experiment, however, all the cells showed significant morphological deformation (Fig. 3c-e). By 1 year, while most of the cells had kept their cytoplasmic material (Fig. 3f), others had lysed and appeared as empty moulds (Fig. 3g). Additionally, after this time period, the silica matrix contained much amorphous organic matter (Fig. 3e, arrow) that probably represents degraded cellular components, as well as trapped cells. The cell wall appeared to be the most resistant component of the cell. TEM observation showed good preservation of the wall structure (S-layer and plasmic membrane) after 1 month (Fig. 4a). But after 4 months, this structure progressively started to lose structural definition and to disappear, hidden by the growing amorphous silica precipitate (Fig. 4b). These processes continued up to 1 year, when only rare fragments of walls can still be distinguished within the silica precipitate (Figs $3 \mathrm{f}$ and $4 \mathrm{c}$ ).

As noted above, a precipitate of amorphous silica developed within $24 \mathrm{~h}$ of fossilization that gradually embedded the whole culture by 1 year. However, silica was also precipitated directly onto and within the cells themselves. Small particles of silica $(10 \mathrm{~nm})$ were observed by SEM on some cell walls at $24 \mathrm{~h}$ (Fig. 2c), although they may simply represent particles that settled onto the cells during sample preparation. By 1 month, TEM observation demonstrated that a fine, up to $10 \mathrm{~nm}$-thick coating of silica had formed (Fig. $2 \mathrm{~g}$ ). This coating increased throughout the experiment (Fig. 3) resulting in complete embedding of the cells in the amorphous silica precipitate by 1 year. Some precipitation of silica particles in the intracellular space had occurred by 4 months (Fig. 3b) and, by 1 year, silica particles could be seen inside lysed and unlysed cells (Fig. 3f,g, arrows).

\section{Methanocaldococcus jannaschii silicification experiment}

In their natural state (Fig. 5a,b), the almost 1- $\mu$ m diameter, coccoidal M. jannaschii cells display a rugged surface texture, described by Jones et al. (1983) as raisin-like. This texture is not due to any osmotic effects or lysis. The cells are bound together by copious quantities of EPS (Fig. 5a, arrow). Figure 5b shows that the EPS form a consistent film with occasional 
filamentous attachments to embedded cells (arrow). As a result of the 'poor' growth medium, cell densities were never very high for this species, even after the exponential growth phase. The injection of the silica solution led to a significant $\mathrm{pH}$ increase, from 6.5 to 7.5-8.0.

The reaction of $M$. jannaschii to the introduction of a saturated silica solution was very different to that of $P$. abyssi. Most striking is the fact that the last observation of a significant number of intact or even lysed cells with the SEM was at 1 week (Fig. 5h,i) and thereafter only a decreasing number of degraded cells or cells remains could be observed on TEM micrographs (Figs $5 \mathrm{j}-1$ and $6 \mathrm{e}, \mathrm{f}$ ).

After $24 \mathrm{~h}$, the cells exhibited good morphological structure (Fig. 5c) and there was no sign of a granular silica precipitate on the cell wall (Fig. 5c,e). On the other hand, a white, gelatinous, siliceous precipitate formed rapidly within a few hours and was visible with the naked eye in the glass bottle containing the incubated samples. This precipitate consisted of $50 \mathrm{~nm}$-sized amorphous silica particles forming an alveolar network structure (Fig. 5c) that appears to have nucleated on the EPS which is entrapped within it (arrow). In some cases, there appears to be an empty aureole of about $100 \mathrm{~nm}$ between the cell envelope and the silica precipitate (Fig. 5f). Lysed cells, on the other hand, were completely embedded in the silica matrix (Fig. 5g). In contrast to P. abyssi, very few cells remained intact after 1 week. Some of these cells had lysed and were completely deformed (Fig. 5h), whereas others still exhibited good morphological structure (Fig. 5i). Rare silica particles were observed on the surfaces of the cells after 1 week (Fig. 5h,i).

One month after the beginning of the experiment, the only feature that could be seen on SEM micrographs was the amorphous silica precipitate that retained its granular, alveolar, reticulate texture in which film-like strands of EPS were clearly visible (Fig. 6a) in cracks formed during the critical-point drying process. Interestingly, the EDX spectra show a small but readily distinguishable $\mathrm{Mg}$ peak probably related to the presence of $\mathrm{MgCl}_{2}$ in the culture medium (Fig. 6b). TEM micrographs showed a moderate number of $M$. jannaschii cells in various states of preservation, including intact cells with cytoplasmic material (Fig. 5j), heavily deformed cells (Fig. 5k) and cellular remains (Fig. 51). Some dark silica particles were observed on the cell wall (Fig. 5j,k, arrows), while $10 \mathrm{~nm}$ thick coating of silica was present on cells remains (Fig. 51).

After 1 year of silicification, the reticulate structure of the silica precipitate was still recognizable (Fig. 6c), but the granular texture was heavier and thicker, a probable sign of continuing precipitation. The EPS were no longer visible, possibly due to their complete decay or coating with silica. The high $\mathrm{C}$ peak in the EDX spectra seems to confirm the latter (Fig. 6d). TEM micrographs showed only a few deformed cells or cells remains (Fig. 6e,f). Small fibrous elements that had formed in the deposit were observed bound to cells and cells remains (Fig. 6e,f).

Cell counts during the growth phase show that the presence of silica in the medium blocked cell growth (Table 3; Fig. 7, growth phase), whereas the $\mathrm{pH}$ increase had no effect. When growth was prolonged beyond the end of the exponential growth phase, cell lysis naturally occurred and about one-third of the cells lysed within $24 \mathrm{~h}$. Neither the presence of silica, nor the increase in $\mathrm{pH}$, either individually or together, had any clear influence on the lysis rate (Table 3; Fig. 7, lysis phase). 


\section{Silica precipitates}

Amorphous silica precipitates formed spontaneously within the control culture media (without cells) for both $P$. abyssi and $M$. jannaschii. In the former case, the precipitate was morphologically similar to that formed in association with the cells, i.e. a dense, finely granular matrix with particles sizes of about $10 \mathrm{~nm}$ (Fig. 8a). EDX analysis of the precipitate detected the presence of $\mathrm{Na}$ in the spectrum (Fig. 8b). The weak $\mathrm{C}$ signal is probably due to the underlying polycarbonate support filter. In the second case, again, the silica precipitate resembled that formed in the $M$. jannaschii culture medium with cells. It exhibited a reticulate, alveolar texture consisting of $50 \mathrm{~nm}$-sized particles (Fig. 8c). However, in this case, there was no evidence for the smooth EPS that were associated with the silica precipitate in the medium with cells (compare Figs $8 \mathrm{~b}$ and 5c). The EDX spectra from this precipitate show a weak $\mathrm{C}$ peak (probably related to the polycarbonate support filter) and a distinct $\mathrm{Mg}$ peak as well as Si (Fig. 8d). TEM micrographs of the silica deposit in the M. jannaschii medium gave additional information about the internal structure of this deposit (Fig. 8e). Most of the deposit consists of granular, electron dense amorphous silica particles. After $24 \mathrm{~h}$, the deposit was, however, heterogeneous and included small, very finely granular globules of material that was less electron dense than the silica. EDX analyses indicate the presence of magnesium in this deposit (Fig. 8f,g). The presence of the Mg in the silica deposit is probably related to $\mathrm{MgCl}_{2}$ from the culture medium. After 1 year, the quantity of amorphous silica particles had significantly decreased (compare Figs 5e and 6f), while most of the deposit was made of small fibrous particles (Fig. 6e,f). EDX analyses made to determine the precise nature of this fibrous deposit were inconclusive.

\section{Discussion}

To our knowledge, this study was the first experimental silicification of members of the Archaea Domain. The two strains used demonstrated different behaviour during the silicification process. Pyrococcus abyssi cells were preserved and silica precipitated on the cell wall, whereas most of $M$. jannaschii cells lysed quickly and only a few cells and cells remains were preserved at the end of the experiment. As the experimental fossilization was performed directly in the culture media, the cells were still living and had access to nutrients at the beginning of the silicification, as in the natural environment. It was thus possible to study the microbial reactions to the injection of silica and to the induced changes in the media.

\section{Silicification of $P$. abyssi and M. jannaschii}

The experimental fossilization of $P$. abyssi was characterized by a gradual thickening crust of amorphous silica around the cell wall and, finally, after 1 year, the precipitation of silica within the empty, silicified casts of the cells (Fig. 3g). Silicification was accompanied by the morphological deformation of the cells (Fig. 3c), disappearance of the cell-wall structure within the silica precipitate (Fig. 4), breakdown of the cell wall, and, finally, lysis and loss of cytoplasmic content (Fig. 3g). A similar sequence of silicification and cell breakdown has previously been described in naturally and artificially silicified Gram-negative Bacteria (Schultze-Lam et al., 1995; Westall et al., 1995; Westall, 1997; Toporski et al., 2002). Interestingly, as previously observed by Westall et al. (1995) and Lalonde et al. (2005), some cells were still alive months after the beginning of the experiment, while others were already trapped in silica, with silica particles bound on their cell wall. Given that the nutrients were exhausted about 3 days after the beginning of silicification (M. Le Romancer, unpublished data) and that $P$. abyssi cannot grow at the fossilization temperature $\left(60^{\circ} \mathrm{C}\right)$ (Erauso et al., 1993), no cell growth could have occurred after a few days of the fossilization. The still-living 
cells probably survived by reducing their metabolic activity and entering into dormancy until death caused by complete encasement in the silica precipitate and, consequently, blockage of exchange between the cell and its environment.

In contrast to $P$. abyssi, the M. jannaschii experiment led to the lysis and the death of most of the cells within a week (Table 3, Fig. 7), and thereafter, only a few cells remained in the rapidly formed alveolar silica precipitate (Figs $5 \mathrm{j}$ and $6 \mathrm{e}$ ) that included amorphous organic carbon representing EPS and lysed cellular components (Figs 51 and 6a,f). Rapid lysis of the $M$. jannaschii cells may have been caused by natural processes or by changes in the culture induced by the sudden injection of silica into the medium, i.e. an increase in $\mathrm{pH}$ (from $\mathrm{pH} 6.5$ to 7.5-8) and a change in the osmotic equilibrium. Separate tests were made in which $M$. jannaschii reaction to osmotic changes (exposure to a 500-ppm silica concentration) or $\mathrm{pH}$ increase (from $\sim 6.5$ to $\sim 7.8$ ) was compared with cell survival in the normal growth medium. They showed that rapid cell lysis is a natural phenomenon after the exponential growth phase and is not related to the presence of silica or to the $\mathrm{pH}$ increase (Fig. 7, lysis phase), even though M. jannaschii cannot grow at $\mathrm{pH}$ values $>7.0$ (Jones et al., 1983). On the other hand, these experiments demonstrate that injection of silica into the culture medium definitely blocked cell growth (Fig. 7, growth phase), resulting in a rapid decrease of cell numbers after the beginning of the silicification. No deposition of amorphous silica particles was noticed on intact M. jannaschii cells during the first week (Fig. 5e,f). There was instead a void space between the cells and the silica precipitate (Fig. 5e). Afterwards, a few cells and cellular remains were observed coated with a thin precipitate of silica (Figs 5j,k,j, and 6e,f), similar to the precipitate on $P$. abyssi cells, and were successfully preserved at the end of the experiment. However, in contrast to P. abyssi, given the rapid early lysis of $M$. jannaschii cells and the very few preserved cellular remains after 1 year, we consider that the silicification of $M$. jannaschii was not successful.

\section{Microbial reaction to silicification}

Some micro-organisms, including $M$. jannaschii, produce EPS in response to environmental stresses (Lapaglia \& Hartzell, 1997; Johnson et al., 2005; Lalonde et al., 2005), and the copious quantities of EPS in the culture of the latter after the injection of silica (Fig. 5c) could be a response to the silicification and the environmental changes it induced. Both particulate and dissolved EPS would have provided passive support for amorphous silica nucleation, becoming subsequently entrapped in the silica precipitate. The importance of EPS is that they fossilize readily owing to the abundant functional groups available for complexing ions (Westall et al., 1995, 2000, and references therein).

Another reaction to silica injection is the possible repulsion of the silica precipitate away from the living cells, creating a void of $\sim 100 \mathrm{~nm}$ around the cells in the $M$. jannaschii experiment (Fig. 5f) and also around P. abyssi cells after 1 month of silicification (Fig. 2f). In contrast, silica occurred in direct contact with the surfaces of lysed M. jannaschii cells (Fig. $5 \mathrm{~g}$ ). Lalonde et al. (2005) noted a similar reaction during the experimental silicification of $S$. azorense and suggested that continuous EPS production could repulse the silica. 


\section{Mechanisms of silicification}

The silica in this experiment was in a monomeric $\left[\mathrm{Si}(\mathrm{OH})_{4}\right]$ or slightly polymeric form (Birnbaum et al., 1989; Toporski et al., 2002; Benning et al., 2004a,b; Lalonde et al., 2005). The high concentrations of silica $(500 \mathrm{ppm})$ in our experiment resulted in the formation of a white precipitate composed of nanometrical particles of amorphous silica within a few hours after the injection of the sodium silica solution (Figs $2 \mathrm{c}$ and $5 \mathrm{c}$ ). After the initial polymerization phase, the dissolved silica concentration remains slightly above the saturation level (Lalonde et al., 2005). Konhauser et al. (2004) noted that silicification proceeds by the binding of nanoparticles of polymeric or colloidal silica onto Bacteria cell walls by hydrogen bonding between the hydroxyl groups of the silica and the cell-wall molecules, identifying peptidoglycan (a hydroxyl and carboxyl-rich polysaccharide) as the main cell-wall component involved in silica binding (Fig. 9). Fixation of silica to the cell components of P. abyssi and $M$. jannaschii and the EPS in the M. jannaschii culture probably occurred in a similar manner. However, as $P$. abyssi and $M$. jannaschii cell walls lack peptidoglycan (Fig. 9), other components must be involved in the binding of silica. The S-layer, composed of glycoproteins and almost ubiquitous among Archaea, is the most likely alternative binding site (Fig. 4a). Indeed, after 4 months of silicification the S-layer of $P$. abyssi was hidden by the silica precipitate (Fig. 4b) and, by the end of the experimental silicification, even the plasmic membrane was no longer visible (Fig. 4c), suggesting that membrane components were also sites for the silica fixation. The fine silica crust that formed on P. abyssi cells (Fig. $2 \mathrm{~g}$ ) and some $M$. jannaschii cells (Fig. $5 \mathrm{j}-1$ ) probably represents the first step in the immobilization of silica, after which fossilization continued by the abiotic polymerization of silica, leading to an increase in particle size.

Silica precipitation occurred slightly faster in the medium containing $M$. jannaschii cells than in the control sample without cells but the rate of mineral precipitation could not be ascertained in the P. abyssi experiment owing to cloudiness caused by the high cell density. Thus, at least in the M. jannaschii experiment, organic matter (cells and EPS) probably provided nucleation sites for the dissolved silica, as indicated by the presence of amorphous organic carbon in the deposit that is not present in the control experiment (compare Fig. 6a,b with Fig. 8c,d). In the $P$. abyssi experiment, there is no discernable difference in the morphology of the abiogenic silica precipitate and the precipitate associated with the cells (compare Figs 2c and 8a). Precipitates in the control experiment contain small amounts of $\mathrm{Na}$, probably resulting from the high $\mathrm{NaCl}$ content of the growth media or from the sodium silicate solution used for the silicification. In addition, small quantities of magnesium were detected in the precipitate formed in the M. jannaschii culture (Figs 6b,d and 8e), whose nutrient medium had relatively high concentrations $\left(3 \mathrm{~g} \mathrm{~L}^{-1}\right)$ of $\mathrm{MgCl}_{2}$ (compared with $0.2 \mathrm{~g} \mathrm{~L}^{-1}$ for P. abyssi) (Nesterchuk \& Makarova, 1970). The presence of these cations led, with time, to the conversion of the initial Mg-containing amorphous silica deposit to a fibrous deposit, possibly a phyllosilicate (Fig. 6e,f), whose mineralogy could not be determined owing to the small quantities of material available.

As noticed by previous studies (Yee et al., 2003; Benning et al., 2004a, b), our experiments indicate that micro-organisms play only a passive role in the precipitation of silica, as the initial precipitation is the result of high silica concentrations, although the precipitation rate is slightly increased by the presence of organic matter. Further growth of the precipitate is due to abiotic polymerization. 
The delicate silica crust forming around $P$. abyssi and the remaining $M$. jannaschii cells is similar to that seen around cells of the Gram-negative Bacteria in the experiments of Westall (1997) and Toporski et al. (2002), indicating that the silicification of Gram-negative Bacteria and Archaea is quite similar in intensity. This is in contrast to thick crusts that formed around Gram-positive Bacteria, whose wall is characterized by a thick layer of peptidoglycan (Westall, 1997). Figure 9 summarizes the relationship between the cell-wall composition and structure and the binding capacities for the different kinds of prokaryotes. The robustness of the mineral crust around the fossilized micro-organisms is probably a strong control on the likelihood of survival of the microfossils in the rock record. This does not mean, however, that silicified Gram-negative Bacteria or Archaea cannot be preserved at all. Rapid cementation around the fossilized cells would aid their preservation.

\section{Preservation of Archaea in the rock record}

This experiment was designed to simulate environmental conditions in the vicinity of hydrothermal systems in the Early Archean (heat, no oxygen). The results of the P. abyssi experiment showed that preservation of Archaea through silicification can occur in such conditions. It is not possible, however, to interpret the silicified micro-organisms, such as those described by Westall et al. (2001, 2006a,b) in hydrothermally silicified sediments from Early Archaean Formations in South Africa and Australia, as representatives of the Archaea Domain purely on the basis of morphology. Certain key features, such as the S-layer and plasmic membrane, started disappearing in the P. abyssi cells after 4 months of silicification (Fig. 4). They therefore have low preservation potential in the rock record.

Previous studies (e.g. Bartley, 1996; Jones et al., 2001, 2004) as well as our experiments have shown the critical importance of the first moments of the silicification process and the necessity of continued survival of cells for periods long enough for the fossilising medium to fix to the cell walls. In the case of P. abyssi, the length of time necessary for the formation of a delicate silica crust on the cell wall was of the order of a few weeks to a few months. Retardation of degradation, for instance by the fixation of $\mathrm{Fe}^{3+}$ to Bacteria cell walls (Ferris et al., 1988), enables prolonged exposure to the fossilising fluids and, therefore, more time for the structures to be coated with silica. On the other hand, the rapid natural lysis of species, such as M. jannaschii, means that this kind of species will probably not be fossilized and preserved in the rock record. The major implication is that the microfossil assemblages occurring in rocks may not necessarily be a representative of the total original community. It will consist principally of those species that are most robust and tolerant to environmental changes. Furthermore, although most of $M$. jannaschii cells were not silicified, their EPS were, underlying the importance of searching for different kinds of microbial products as biosignatures (Westall et al., 2000; Handley et al., 2008).

Another aspect of the rapidity of fossilization is the potential for the preservation of fine-scale details that can be critical to interpretations of biogenicity. Coccoidal microfossils in a 3.466Ga-old chert from the Pilbara Craton exhibit surface textural details of the order of tens of nanometres, such as cell division menisci and rugged surface textures (Westall et al., 2006a; Fig. 1), that are very similar to the deformed $P$. abyssi cells after some months of fossilization (e.g. Fig. 3d), suggesting that the Early Archaean cells had also been coated by a delicate crust of silica (Westall, 2008). These features, amongst other biosignatures, aided distinction of the fossilized coccoids from, for example, abiotic hydrothermal silica spheres (Westall, 2008). 
After the initial fossilization process, various factors, such as diagenesis, metamorphism and weathering, can lead to the alteration or the destruction of the microfossils in the succeeding stages of sedimentation. However, the fact that silicified microbial cells have been found in up to 3.466-Ga-old silicified sediments from South Africa and Australia, where the mineral matrix is microcrystalline quartz that, in places, has been recrystallized (Westall et al., 2001, 2006a,b), shows that the fossilization process was efficient enough to preserve the morphology of the micro-organisms and organic matter up to the present time. Thus, failure to fossilize is more likely due to the lack of preservation of micro-organisms in the short period of time following the death of the cells, rather than to the subsequent geological history of the rocks containing the fossilized micro-organisms.

Our experimental silicification of micro-organisms from the Archaea Domain also has applications in the search of life on Mars. As noted above, the evidence for relatively large quantities of liquid water on Early Mars (Bibring et al., 2005; Poulet et al., 2005; Carr, 2006) indicates that the environmental conditions on the early planet were conducive for the appearance of life. If life appeared on Mars, there is a high probability that the traces of those life forms were preserved by fossilization with silica or other minerals. Indeed, amorphous silica deposits of probable hydrothermal origin have been recently discovered (Squyres et al., 2008). As the Martian surface was not exposed to tectonic or metamorphic processes in the extent that occurred on Earth, sedimentary rocks must still exist in the Early Noachian terrains that cover a large part of the southern highlands of Mars. This gives high hopes for the finding of possible past Martian life forms.

\section{Conclusions}

These experiments are the first to experimentally fossilize micro-organisms from the Archaea Domain and have contributed important information for understanding the fossilization processes of such micro-organisms. They have demonstrated significant differences in the susceptibility to fossilization of two, quite similar strains (kingdom, cell-wall structure), $M$. jannaschii and P. abyssi. Exposition to a silica solution in near natural conditions, simulating a hydrothermal environment in the Archaean period (anaerobic, hot, silica saturation of $\sim 500 \mathrm{ppm}$, nutrient availability) resulted in the preservation of $P$. abyssi but not the $M$. jannaschii cells.

A delicate silica crust formed on the $P$. abyssi cells by 1 month of silicification, which continued to thicken over the 1 year of the experiment. As the experiments were undertaken in the growth medium, $P$. abyssi cells remained viable for several months in a medium saturated with respect to silica, without any additional nutrient supply. The silicification process therefore affected the cells progressively, over a period of several months, thus aiding cell preservation. In contrast, most of $M$. jannaschii cells lysed rapidly within a couple of weeks exposure to the silicifying fluids, and, apart from a few cells and cell remains, decayed before silicification could preserve them. The lysis was a natural phenomenon, not provoked by exposure to the silica solution. On the other hand, the EPS of the $M$. jannaschii culture were trapped in the silica precipitate within $24 \mathrm{~h}$ exposure and were well preserved. There is some evidence that $M$. jannaschii cells attempted to protect themselves from the silica deposit while they were still living. A granular amorphous silica precipitate also embedded the $P$. abyssi cells. These precipitates formed spontaneously owing to the saturation of the silica solution but their rate of formation may have been slightly enhanced by the presence of organic components (cell walls and EPS) onto which they could fix. 
The differences observed between the two strains studied suggest that, as not all microorganisms can be preserved by fossilization microfossils found in the rock record are only a part of the original communities. Our experiments underline the delicacy of the silicification of the P. abyssi cell walls and the level of textural detail that can be preserved in silicified micro-organisms. This is born out by comparison with $\sim 3.5$ Ga-old silicified micro-organisms in Early Arcahean cherts from the Barberton greenstone belt and the Pilbara Craton. The fast and efficient fossilization of the EPS highlights the fact that the search for traces of early terrestrial and extraterrestrial (Martian) life must not be focused only on the detection of cells remains, but also on all different kind of microbial products. Given the traces of hydrothermal amorphous silica on Mars, the results of our experiments are of direct relevance to the search for traces of life in Martian materials.

\section{Acknowledgements}

This study was financially supported by the CNRS and CNES. The authors would like to warmly thank Annie Richard for technical assistance, and Dominique Jalabert for the help for the electronic microscopy, and Valentin Crépeau for precious assistance in the culture experiments. Comments by anonymous reviewers on a previous version of this manuscript were extremely helpful. 


\section{References}

Allwood AC, Walter MR, Kamber BS, Marshall CP, Burch IW (2006) Stromatolite reef from the Early Archaean era of Australia. Nature 441, 714-718.

Allwood AC, Grotzinger JP, Knoll AH, Burch IW, Andreson MS, Colemans ML, Kanik I (2009) Controls on development and diversity of Early Archaean stromatolites. Proceedings of the National Academy of Sciences of the USA 106, 9548-9555.

Balch WE, Wolfe RS (1976) New approach to the cultivation of methanogenic bacteria: 2mercaptoethanesulfonic acid (HS-CoM)-dependent growth of Methanobacterium ruminantium in a pressurized atmosphere. Applied and Environmental Microbiology 32, 781791.

Bartley JK (1996) Actualistic taphonomy of cyanobacteria; implications for the Precambrian fossil record. Palaios 11, 571-586.

Benning LG, Phoenix VR, Yee N, Tobin MJ (2004a) Molecular characterization of cyanobacterial silicification using synchrotron infrared micro-spectroscopy. Geochimica et Cosmochimica Acta 68, 729-741.

Benning LG, Phoenix VR, Yee N, Konhauser KO (2004b) The dynamics of cyanobacterial silicification: an infrared micro-spectroscopic investigation. Geochimica et Cosmochimica Acta 68, 743-757.

Beveridge TJ (2001) Bacterial cell wall. In: Encyclopedia of Life Science. Nature Publishing Group, London, doi: 10.1038/ npg.els.0000297.

Bibring JP, Langevin Y, Gendrin A, Gondet B, Poulet F, Berthé M, Soufflot A, Arvidson R, Mangold N, Mustard J, Drossart P, the OMEGA team (2005) Mars surface diversity as revealed by the OMEGA/Mars Express Observations. Science 307, 1576-1581.

Birnbaum SJ, Wireman JW, Borowski R (1989) Silica precipitation by the anaerobic sulphate reducing bacterium Desulfovibrio desulfuricans: effects upon cell morphology and 
implications for preservation. In Origin, Evolution, and Modern Aspects of Biomineralization in Plants and Animals (ed. Crick RE). Plenum Press, New York, pp. 507-516.

van den Boorn SHJM, van Bergen MJ, Nijman W, Vroon PZ (2007) Dual role of seawater and hydrothermal fluids in Early Archean chert formation: Evidence from silicon isotopes. Geology 35, 939-942.

Brasier MD, Green OR, Jephcoat AP, Kleppe AK, Van Kranendonk MJ, Lindsay JF, Steele A, Grassineau NV (2002) Questioning the evidence for Earth' oldest fosils. Nature 416, 7681.

Cady SL, Farmer JD (1996) Fossilization processes in siliceous thermal springs: trends in preservation along thermal gradients. Ciba Foundation Symposium 202, 150-170.

Carr MH (2006) The Surface of Mars. Cambridge University Press, Cambridge.

Erauso G, Reysenbach AL, Godfroy A, Meunier JR, Crump B, Partensky F, Baross JA, Marteinsson V, Barbier G, Pace NR, Prieur D (1993) Pyrococcus abyssi sp. nov., a new hyperthermophilic archaeon isolated from a deep-sea hydrothermal vent. Archives of Microbiology 160, 338-349.

Ferris FG, Fyfe WS, Beveridge TJ (1988) Metallic ion binding by Bacillus subtilis; implications for the fossilization of microorganisms. Geology 16, 149-152.

Forterre P, Brochier C, Philippe H (2002) Evolution of the Archaea. Theoretical Population Biology 61, 409-422.

Francis S, Margulis L, Barghoorn ES (1978) On the experimental silicification of microorganisms. II. On the time of appearance of eukaryotic organisms in the fossil record. Precambrian Research 6, 65-100.

Geslin C, Le Romancer M, Erauso G, Gaillard M, Perrot G, Prieur D (2003) PAV1, the first virus-like particle isolated from a hyperthermophilic Euryarchaeote, "Pyrococcus abyssi". Journal of Bacteriology 185, 3888-3894. 
Grotzinger JP, Kasting J (1993) New constraints on Precambrian ocean composition. Journal of Geology 101, 235-243.

Handley KM, Campbell KA, Mountain BW, Browne PRL (2005) Abiotic-biotic controls on the origin and development of spicular sinter: in situ growth experiments, Champagne Pool, Waiotapu, New Zealand. Geobiology 3, 93-114.

Handley KM, Turner SJ, Campbell KA, Mountain BW (2008) Silicifying biofilm exopolymers on a hot-spring microstromatolite: templating nanometer-thick laminae. Astrobiology 8, 747-770.

Hofmann A, Bolhar R (2007) Carbonaceous Cherts in the Barberton Greenstone Belt and Their Significance for the Study of Early Life in the Archaean Record. Astrobiology 7, 355388.

Johnson MR, Montero CI, Conners SB, Shockley KR, Bridger SL, Kelly RM (2005) Population density-dependent regulation of exopolysaccharide formation in the hyperthermophilic bacterium Thermotoga maritima. Molecular Microbiology 55, 664-674.

Jones WJ, Leigh JA, Mayer F, Woese CR, Wolfe RS (1983) Methanococcus jannaschii sp. nov., an extremely thermophilic methanogen from a submarine hydrothermal vent. Archives of Microbiology 136, 254-261.

Jones B, Renaut RW, Rosen MR (1998) Microbial biofacies in hot-spring sinters: a model based on Ohaaki Pool, North Island, New Zealand. Journal of Sedimentary Research 68, 413434.

Jones B, Renaut RW, Rosen MR (2001) Taphonomy of silicified filamentous microbes implications for identification. Palaios 16, 580-592.

Jones B, Renaut RW, Rosen MR (2003) Silicified microbes in a geyser mound: the enigma of low-temperature cyanobacteria in a high-temperature setting. Palaios 18, 87-109. 
Jones B, Konhauser KO, Renaut R, Wheeler R (2004) Microbe silicification in Iodine Pool, Waimangu geothermal area, North Island, New Zealand: implications for recognition and identification of ancient silicified microbes. Journal of the Geological Society of London 161, 983-993.

Kandler O, König H (1998) Cell wall polymers in Archaea. Cellular and Molecular Life Sciences 54, 305-308.

Kasting JF (1993) Earth's early atmosphere. Science 259, 920-926.

Knauth LP, Lowe DR (2003) High Archean climatic temperature inferred from oxygen isotope geochemistry of cherts in the 3.5 Ga Swaziland Supergroup, South Africa. Geological Society of Amercia Bulletin 115, 566-580.

Konhauser KO, Ferris FG (1996) Diversity of iron and silica precipitation by microbial mats in hydrothermal waters, Iceland : implications for Precambrian iron formations. Geology 24, $323-326$.

Konhauser KO, Phoenix VR, Bottrell SH, Adams DG, Head IM (2001) Microbial-silica interactions in Icelandic hot spring sinter : possible analogues for Precambrian siliceous stromatolites. Sedimentology 48, 415-433 .

Konhauser KO, Jones B, Phoenix VR, Ferris G, Renaut RW (2004) The microbial role in hot spring silicification. Ambio 33, 552-558.

König H (2002) Archaeal cell walls. In Encyclopedia of Life Science. Nature Publishing Group, London, 2, 150-161. Doi: 10.1038/ npg.els.0000384.

Lalonde SV, Konhauser KO, Reysenbach AL, Ferris FG (2005) The experimental silicification of Aquificales and their role in hot spring formation. Geobiology 3, 41-52.

Lapaglia C, Hartzell PL (1997) Stress-induced production of biofilm in the Hyperthermophile Archaeoglobus fulgidus. Applied and Environmental Microbiology 63, 3158-3163. Links 
Mountain BW, Benning LG, Boerema J (2003) Experimental studies on New Zealand hot spring sinters: rates of growth and trace metal incorporation. Canadian Journal of Earth Sciences 40, 1643-1667.

Nesterchuk NI, Makarova TA (1970) The formation of aqueous magnesium silicate in the interaction of solutions of magnesium chloride and sodium metasilicate. Russian Chemical Bulletin 19, 2053-2055.

Oehler JH (1976) Experimental studies in Precambrian paleontology: structural and chemical changes in blue-green algae during simulated fossilization in synthetic chert. The Geological Society of America Bulletin 87, 117-129.

Oehler JH, Schopf JW (1971) Artificial microfossils: experimental studies of permineralization of blue-green algae in silica. Science 174, 1229-1231.

Orberger B, Rouchon V, Westall F, de Vries ST, Wagner C, Pinti DL (2006) Protoliths and micro-environments of some Archean Cherts (Pilbara, Australia). Geological Society of America Special Paper 405, 133-152.

Patel GB, Sprott GD (2006) Archaeal membrane lipids. In: Encyclopedia of Life Science. Nature Publishing Group, London, doi: 10.1038/npg.els.0004316.

Pflug HD, Jaeschke-Boyer H (1979) Combined structural and chemical analysis of 3,800Myr-old microfossils. Nature 280, 483-486.

Phoenix VR, Adams DG, Konhauser KO (2000) Cyanobacterial viability during hydrothermal biomineralization. Chemical Geology 169, 329-338.

Poulet F, Bibring JP, Mustard JF, Gendrin A, Mangold N, Langevin Y, Arvidson RE, Gondet B, Gomez C (2005) Phyllosilicates on Mars and implications for early martian climate. Nature 438, 623-627.

Rasmussen B, Fletcher IR, Brocks JJ, Kilburn MR (2008) Reassessing the first appearance of eukaryotes and cyanobacteria. Nature 455, 1101-1104. 
Robert F, Chaussidon M (2006) A palaeotemperature curve for the Precambrian oceans based on silicon isotopes in cherts. Nature 443, 969-972.

Schopf JW (1993) Microfossils of the Early Arcaean Apex Chert: new evidence of the antiquity of life. Science 260, 640-646.

Schopf JW, Kudryavtsev AB, Agresti DG, Wdowiak TJ, Czaja AD (2002) Laser-Raman imagery of Earth's earliest fossils. Nature 416, 73-76.

Schultze-Lam S, Ferris FG, Kohnauser KO, Wiese RG (1995) In situ silicification of an Icelandic microbial mat: implications for microfossil formation. Canadian Journal of Earth Sciences 32, 2021-2026.

Sleytr UB, Beveridge TJ (1999) Bacterial S-layers. Trends in Microbiology 7, 253-260.

Sleytr UB, Sára M (1997) Bacterial and archaeal S-layer proteins: structure-function relationships and their biotechnological applications. Trends in Biotechnology 15, 20-26.

Squyres SW, Arvidson RE, Ruff S, Gellert R, Morris RV, Ming DW, Crumpler L, Farmer JD, Des Marais DJ, Yen A, McLennan SM, Calvin W, Bell III JF, Clark BC, Wang A, McCoy TJ, Schmidt ME, de Souza PA JR (2008) Detection of silica-rich deposits on Mars. Science 320, $1063-1067$.

Tice MM, Lowe DR (2004) Photosynthetic microbial mats in the 3,416-Myr-old ocean. Nature 431, 522-523.

Tice MM, Lowe DR (2007) Tectonic controls on atmospheric, climatic, and biological evolution 3.5-2.4 Ga. Precambrian Research 158, 177-197.

Toporski JKW, Steele A, Westall F, Thomas-Keprta KL, McKay DS (2002) The simulated silicification of bacteria - new clues to the modes and timing of bacterial preservation and implications for the search for extraterrestrial microfossils. Astrobiology 2, 1-26. 
Urrutia MM, Beveridge TJ (1994) Formation of fine-grained silicate minerals and metal precipitates by a bacterial surface (Bacillus subtilis). Chemical Geology 116, 261-280.

Walsh MM (1992) Microfossils and possible microfossils from the Early Archean Onverwacht Group, Barberton Mountain Land, South Africa. Precambrian Research 54, $271-$ 293.

Walsh MM (2004) Evaluation of early Archean volcanoclastic and volcanic flow rocks as possible sites for carbonaceous fossil microbes. Astrobiology 4, 429-437.

Walter MR, Bauld J, Brock TD (1972) Siliceous algal and bacterial stromatolites in hot springs and geyser effluents of Yellowstone National Park. Science 178, 402-405.

Westall F (1997) The influence of cell wall composition on the fossilization of bacteria and the implications for the search for early life forms. In Astronomical and Biochemical Origins and the Search for Life in the Universe (eds Cosmovici C, Bowyer S, Werthimer D). Editori Compositrici, Bologna, pp. 491-504.

Westall F (2008) Morphological biosignatures in terrestrial and extraterrestrial materials. Space Science Reviews 135, 95-114.

Westall F, Folk RL (2003) Exogenous carbonaceous microstructures in Early Archaean cherts and BIFs from the Isua greenstone belt: implications for the search for life in ancient rocks. Precambrian Research 126, 313-330.

Westall F, Southam G (2006) The early record of life. Archean Geodynamics and Environments 164, 283-304.

Westall F, Boni L, Guerzoni E (1995) The experimental silicification of microorganisms. Paleontology 38, 495-528.

Westall F, Steele A, Toporski J, Walsh M, Allen C, Guidry S, McKay D, Gibson E, Chaftez H (2000) Polymeric substances and biofilms as biomarkers in terrestrial materials: 
implications for extraterrestrial samples. Journal of Geophysical Research 105, 2451124527.

Westall F, de Wit MJ, Dann J, van der Gaast S, de Ronde CEJ, Gerneke D (2001) Early Archean fossil bacteria and biofilms in hydrothermally-influenced sediments from the Barberton greenstone belt, South Africa. Precambrian Research 106, 93-116.

Westall F, de Vries ST, Nijman W, Rouchon V, Orberger B, Pearson V, Watson J, Verchovsky A, Wright I, Rouzaud JN, Marchesini D, Severine A (2006a) The 3.466 Ga "Kitty's Gap Chert", an early Archean microbial ecosystem. Geological Society of America special paper 405, 105-131.

Westall F, de Ronde CEJ, Southam G, Grassineau N, Colas M, Cockell C, Lammer H (2006b) Implication of a 3.472-3.333 Gyr-old subaerial microbial mat from the Barberton greenstone belt, South Africa for the UV environmental conditions on the ealry Earth. Philosophical Transactions of the Royal Society B 361, 1857-1875.

Yee N, Phoenix VR, Konhauser KO, Benning LG, Ferris FG (2003) The effect of cyanobacteria on silica precipitation at neutral $\mathrm{pH}$ : implications for bacterial silicification in geothermal hot springs. Chemical Geology 199, 83-90. 
Figures
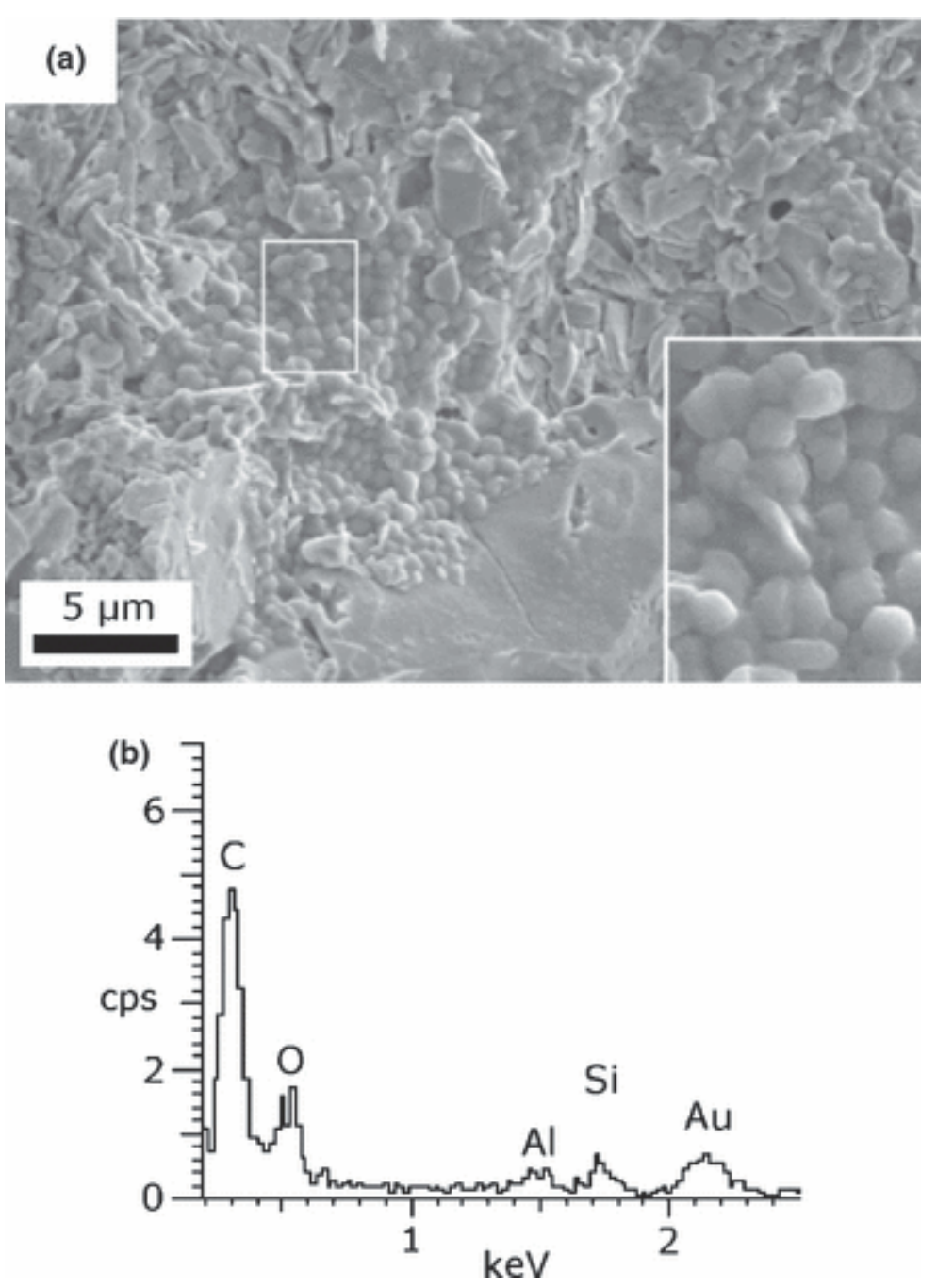

Fig. 1 (a) Silicified colony of coccoidal microfossils from the 3.466 Ga-old Kitty's Gap Chert in the Pilbara Craton, Australia (Westall et al., 2006a) and (b) corresponding EDX spectrum taken at $5 \mathrm{kV}$. 

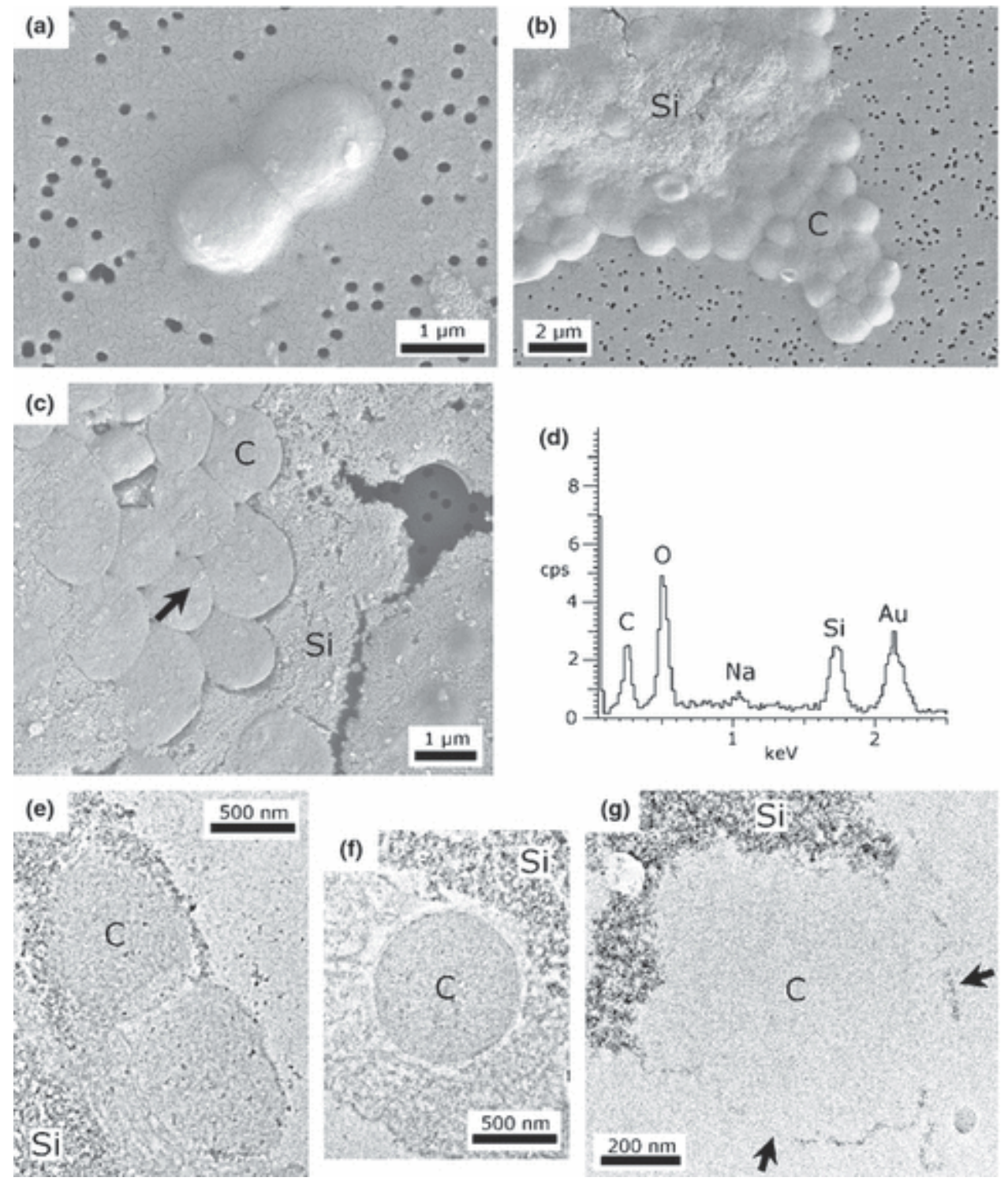

Fig. 2 SEM and TEM micrographs showing examples of fresh Pyrococcus abyssi cells and cells exposed to a 500-ppm silica solution for various lengths of time. SEM micrographs : (a) fresh, dividing, unsilicified cells; (b) $24 \mathrm{~h}$, aggregate of cells (C) and light silica precipitate (Si); (c) $24 \mathrm{~h}$, cells (C) trapped in the amorphous silica precipitate (Si); silica particles are visible on the cells (arrow); EDX spectrum (d) made on the silica precipitate. Note the small $\mathrm{Na}$ peak in the EDX spectrum. All SEM micrographs were made with a 2-kV voltage, and the EDX spectrum with a 5-kV voltage. TEM micrographs: (e) 1 month, cells with silica deposited around the cell envelope; (f) 1 month, intact cell (C), note that there is no direct contact between the cell wall and the silica precipitate (Si); (g) 1 month, a 10-nm thick coating of silica particles (arrows) around the envelop of a cell (C) in an uncontrasted section; note the irregular outline of the cell. All TEM micrographs were made at $200 \mathrm{kV}$ on thin sections stained with lead citrate and uranyl acetate, unless otherwise stated. 

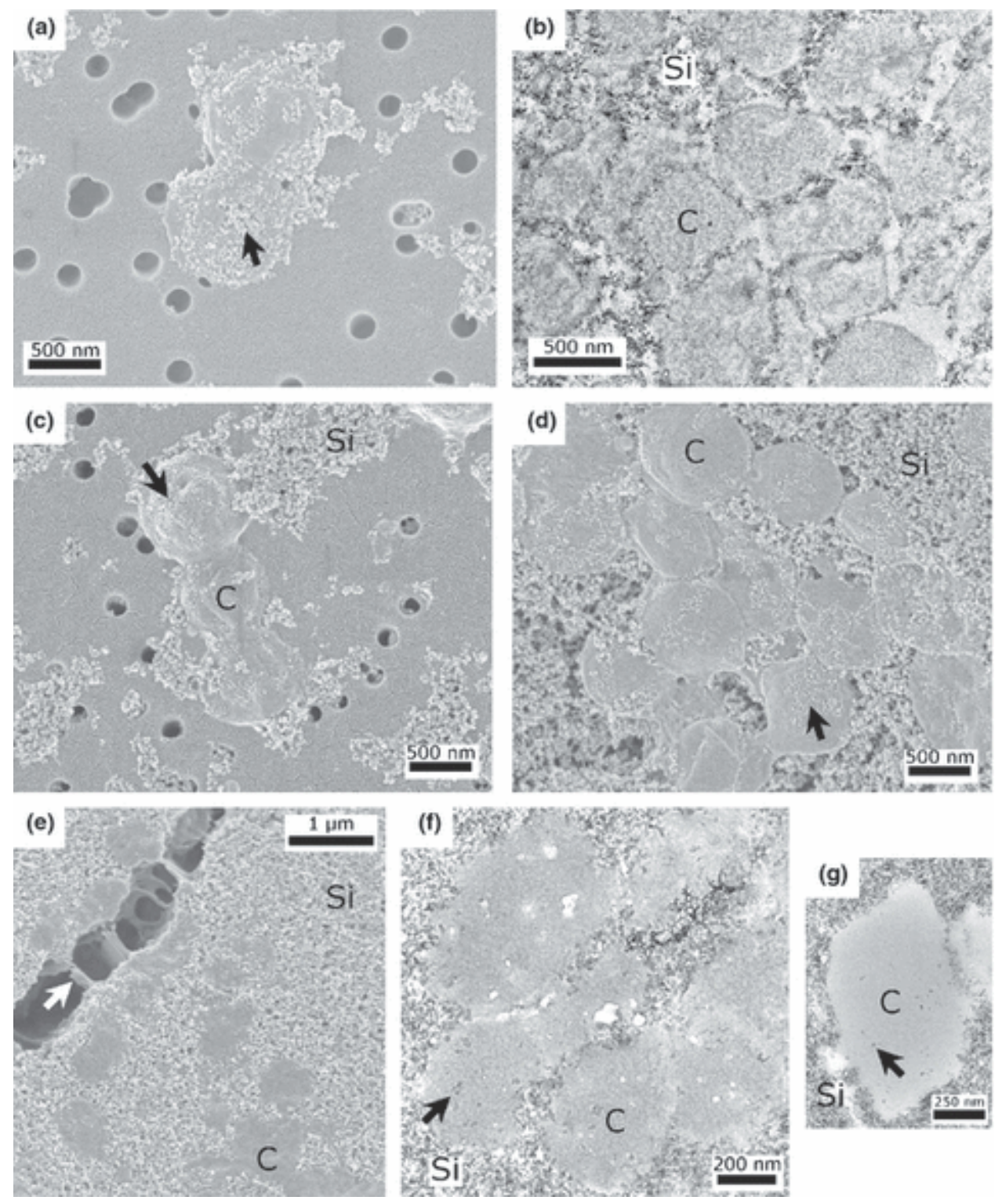

Fig. 3 SEM and TEM micrographs, showing examples of Pyrococcus abyssi cells exposed to a 500-ppm silica solution for various lengths of time. (a) Four months, SEM, isolated cells; amorphous silica particles which have precipitated on the cell wall are clearly visible (arrow). (b) Four months, TEM, closely packed cells (C) in a silica precipitate ( $\mathrm{Si}$ ); the cells show some deformation. (c) Nine months, SEM, isolated cells (C); the cells are no longer turgid and exhibit an irregular, rugged surface; silica particles precipitated on the cell wall are visible (arrows). (d) Nine months, SEM, cells trapped (C) in the silica precipitate (Si); silica particles precipitated on the cell wall are visible (arrows). (e) One year, SEM, cells (C) trapped within the silica precipitate $(\mathrm{Si})$, amorphous organic matter is visible within cracks in the precipitate (arrow). (f) One year, TEM, closely packed unlysed but deformed cells (C) in the silica precipitate $(\mathrm{Si})$, silica particles are visible inside cells (arrow). (g) Lysed cell (C) inside the silica precipitate $(\mathrm{Si})$, silica particles are visible inside the cell (arrow). All SEM micrographs were made at $2 \mathrm{kV}$, and all TEM micrographs at $200 \mathrm{kV}$ on thin sections stained with lead citrate and uranyl acetate. 

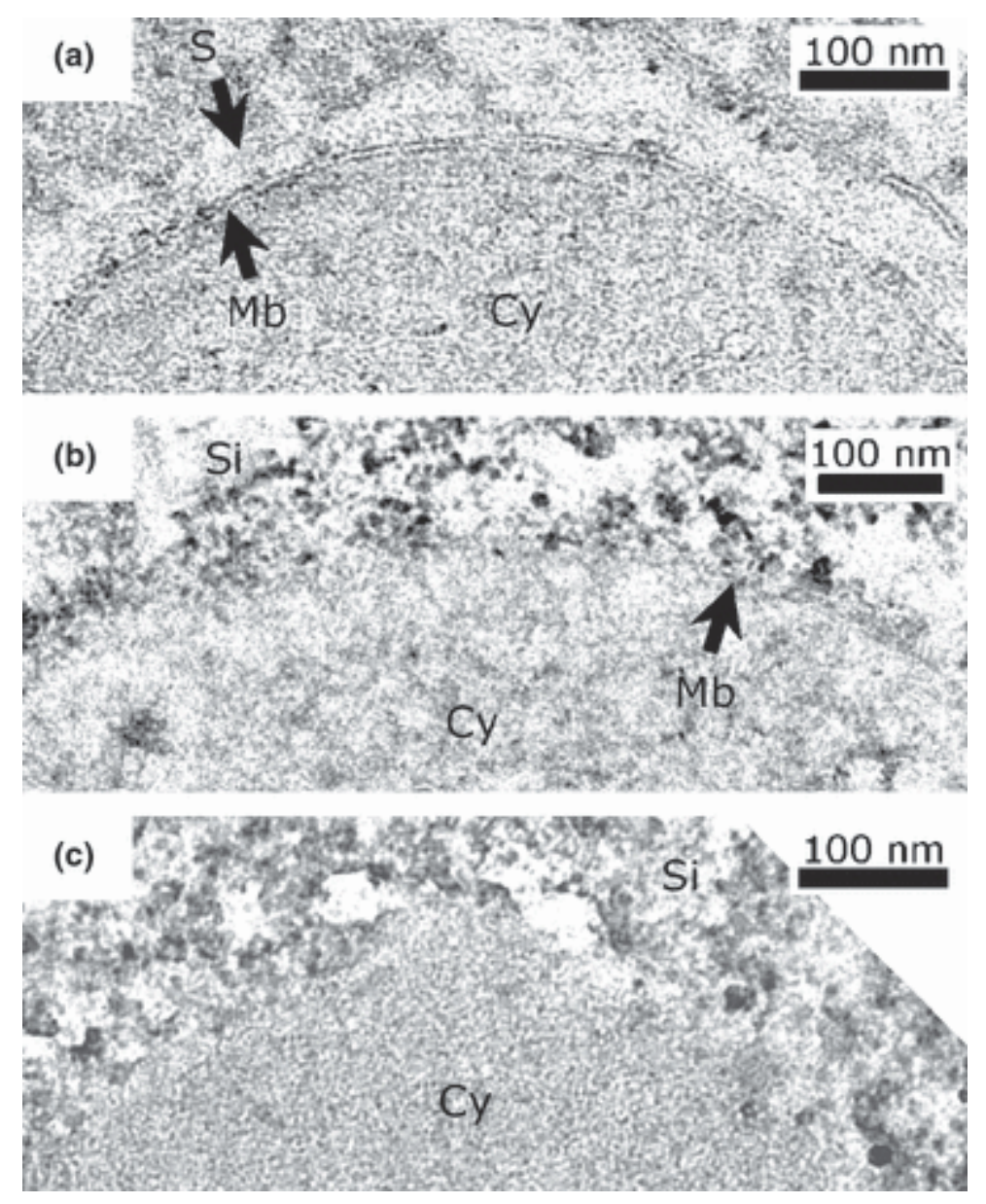

Fig. 4 TEM micrographs showing details of the walls of Pyrococcus abyssi cells exposed to a 500-ppm silica solution for various lengths of time. (a) One month, the plasmic membrane (Mb arrow) and the S-layer (S arrow) are still visible. (b) Four months, only the plasmic membrane ( $\mathrm{Mb}$ arrow) is visible to which the silica crystallites ( $\mathrm{Si}$ ) are directly attached. (c) One year, no detail of the structure of the cell wall can be seen. 

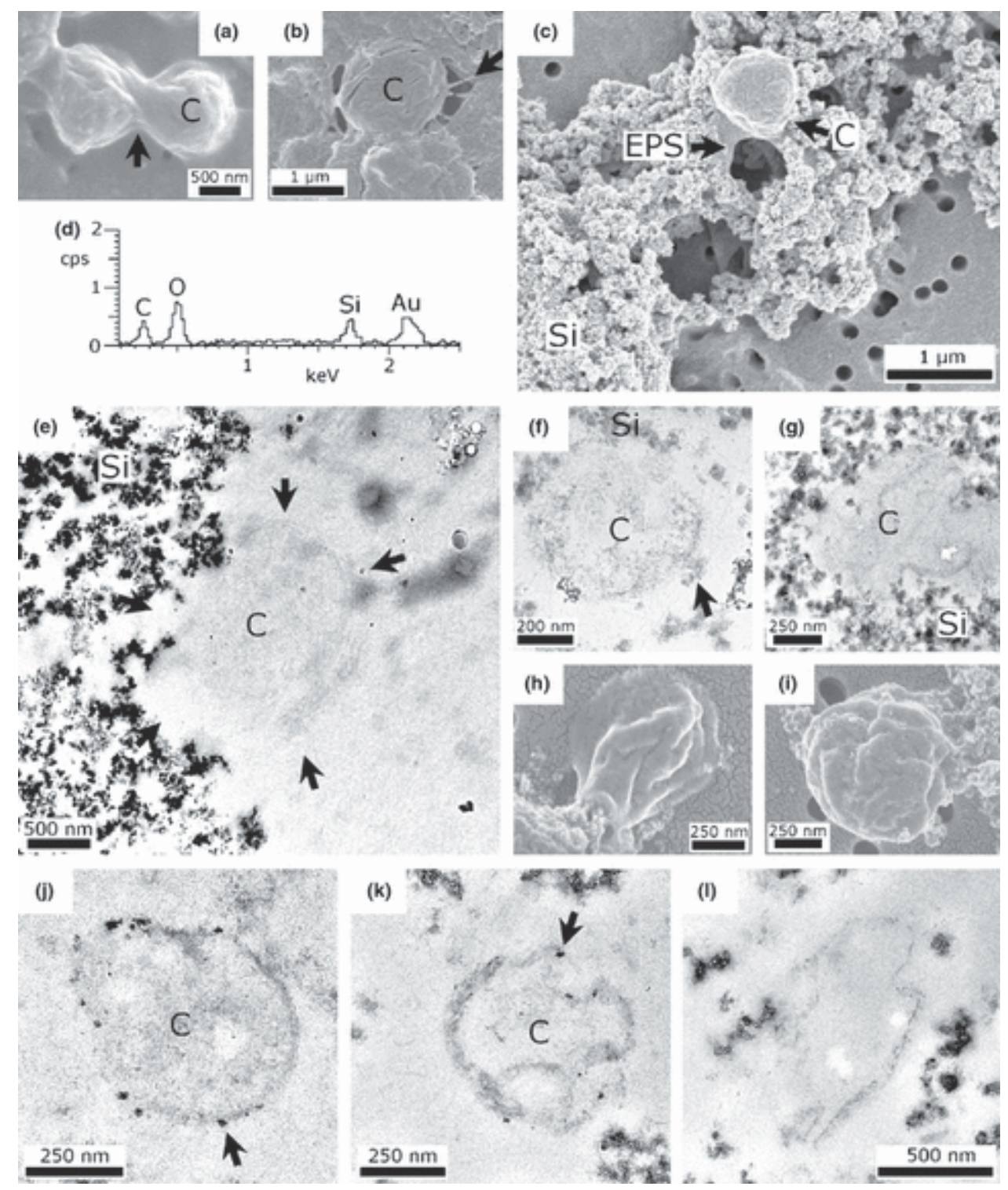

Fig. 5 SEM and TEM micrographs showing examples of fresh cells and EPS of Methanocaldococcus jannaschii and cells exposed to a 500-ppm silica solution for various lengths of time. (a) SEM, fresh, dividing, unsilicified cells (C), linked by sticky EPS (arrow); note the naturally, very irregular morphology of the cell envelope. (b) SEM, cell trapped (C) in the EPS matrix (EPS) with filamentous EPS (arrow). (c) Twenty-four hours, SEM, cells (C) within the silica (Si) precipitated on EPS (EPS), with the corresponding EDX spectrum (d) made on the silica/EPS precipitate. (e) Twenty-four hours, TEM, unstained section of a cell (C); the faint outline of the cell is indicated by arrows. Only in a few locations is the silica precipitate $(\mathrm{Si})$ directly attached to the cell wall. (f) Twenty-four hours, TEM, intact cell (C) trapped in a silica precipitate $(\mathrm{Si})$. Note the halo of void space around it. Only in two places have small granular deposits of silica started to attach to the cell wall (arrow). (g) Twentyfour hours, TEM of lysed cell (C) embedded in the silica precipitate (Si). There is no halo of void space around the cell and the silica precipitate directly touches it. (h) One week, SEM, lysed cell. (i) One week, SEM, intact cell. (j) One month, TEM, intact cell; note the silica particles attached to the cell wall (arrow). (k) One month, TEM, heavily deformed cell; note the silica particles attached to the cell wall (arrow). (1) One month, TEM, cell remains on an unstained section, coated with a thin layer ( $10 \mathrm{~nm}$ ) of silica. All SEM micrographs were 
made at $2 \mathrm{kV}$, the EDX spectrum at $5 \mathrm{kV}$ and the TEM micrographs at $200 \mathrm{kV}$, on thin sections stained with lead citrate and uranyl acetate, unless otherwise stated.
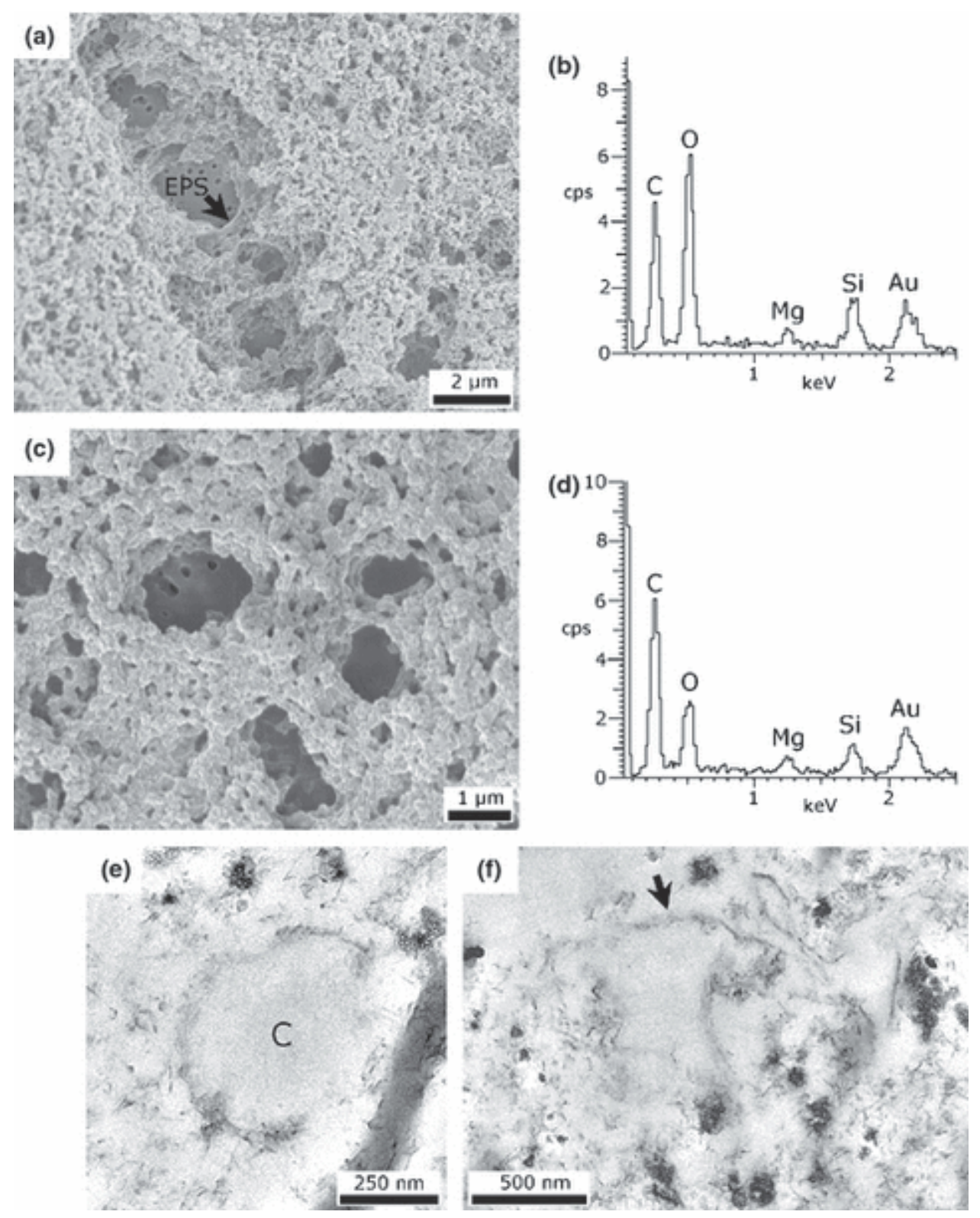

Fig. 6 SEM and TEM micrographs, showing examples of Methanocaldococcus jannaschii cells and EPS exposed to a 500-ppm silica solution for various lengths of time. (a) One month, SEM, EPS (EPS) visible within cracks of the open, alveolar silica precipitate. EDX Spectrum in (b) made on the whole precipitate; note the Mg peak in the spectrum. (c) One year, SEM, the open, alveolar network structure of the silica precipitate is further pronounced and the silica particles are slightly larger. EDX spectrum in (d) made on the whole precipitate; note the $\mathrm{Mg}$ peak in the spectrum. (e) One year, TEM, heavily deformed cell (C); note the fibrous deposit around the cell and on the cell wall. (f) One year, TEM, cell remains within the precipitate (arrow); note the fibrous nature of deposit around the remains, and the relatively low number of electron dense silica particles, in comparison with the early steps of the silicification (Fig. 5e). All SEM micrographs were made at $2 \mathrm{kV}$, EDX spectra at $5 \mathrm{kV}$ and all TEM micrographs at $200 \mathrm{kV}$ on thin sections stained with lead citrate and uranyl acetate. 


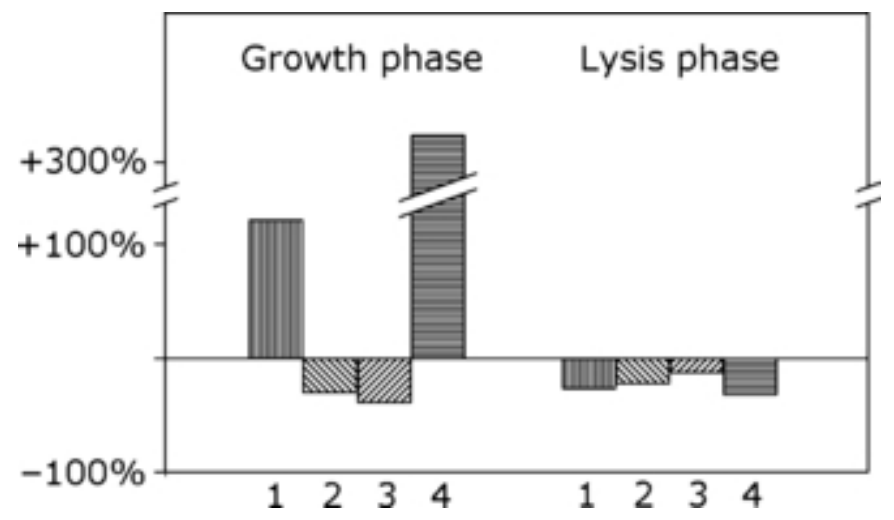

Fig. 7 Influence of several parameters on the Methanocaldococcus jannaschii cell numbers, tested during the exponential growth phase and the lysis phase. The data show the evolution of cell numbers after $24 \mathrm{~h}$ exposure in the silica solution. 1: control sample; 2:

$\left[\mathrm{SiO}_{2}\right]=500 \mathrm{ppm} ; 3:\left[\mathrm{SiO}_{2}\right]=500 \mathrm{ppm}, \mathrm{pH}$ adjusted to initial value; 4: $\mathrm{pH}$ increased.
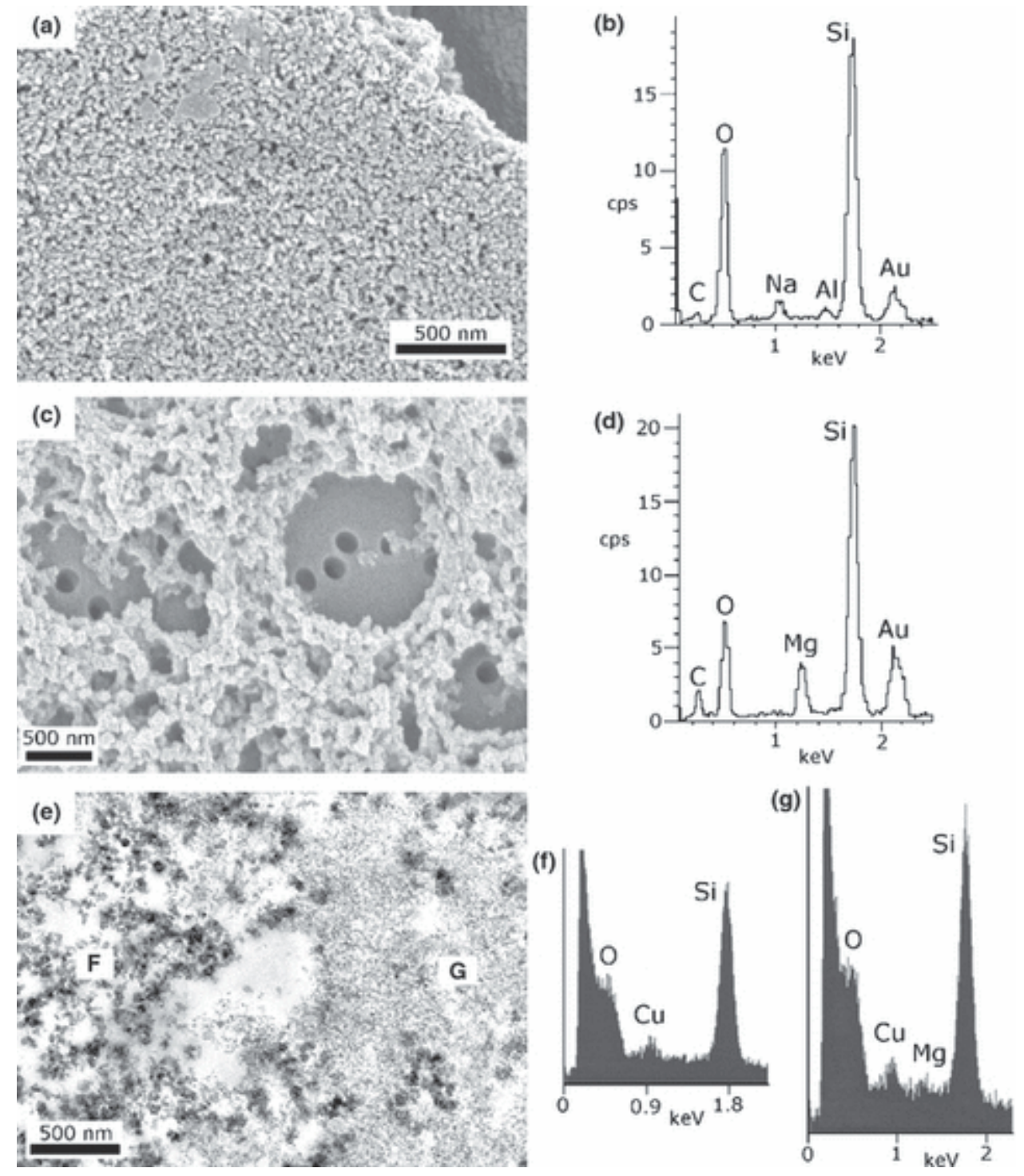

Fig. 8 SEM micrographs, with the corresponding EDX spectra, showing examples of the silica precipitate formed spontaneously in the Pyrococcus abyssi and Methanocaldococcus 
jannaschii control samples, which contained no cells. (a) Amorphous silica precipitate formed spontaneously in the P. abyssi culture medium, after one month. (b) Corresponding EDX spectrum; note the Na peak. (c) Amorphous silica precipitate formed spontaneously in the $M$. jannaschii culture medium, after 1 month. (d) Corresponding EDX spectrum; note the Mg peak. Note the same open, alveolar structure as in the inoculated experiment (Fig. 4c) (N.B. the $\mathrm{C}$ peaks in these spectra come from the underlying polycarbonate filter onto which the precipitate had been filtered) (e) TEM micrograph of the silica precipitate in the M. jannaschii medium after $24 \mathrm{~h}$, which contains two phases with different electron densities: a dark, electron-dense granular material and a less electron dense material. The corresponding EDX spectra in (f) and (g) indicate that the latter contains Mg. All SEM micrographs were made at $2 \mathrm{kV}$ and the EDX spectra at $10 \mathrm{kV}$. The TEM micrograph and EDX spectra were made at $200 \mathrm{kV}$.

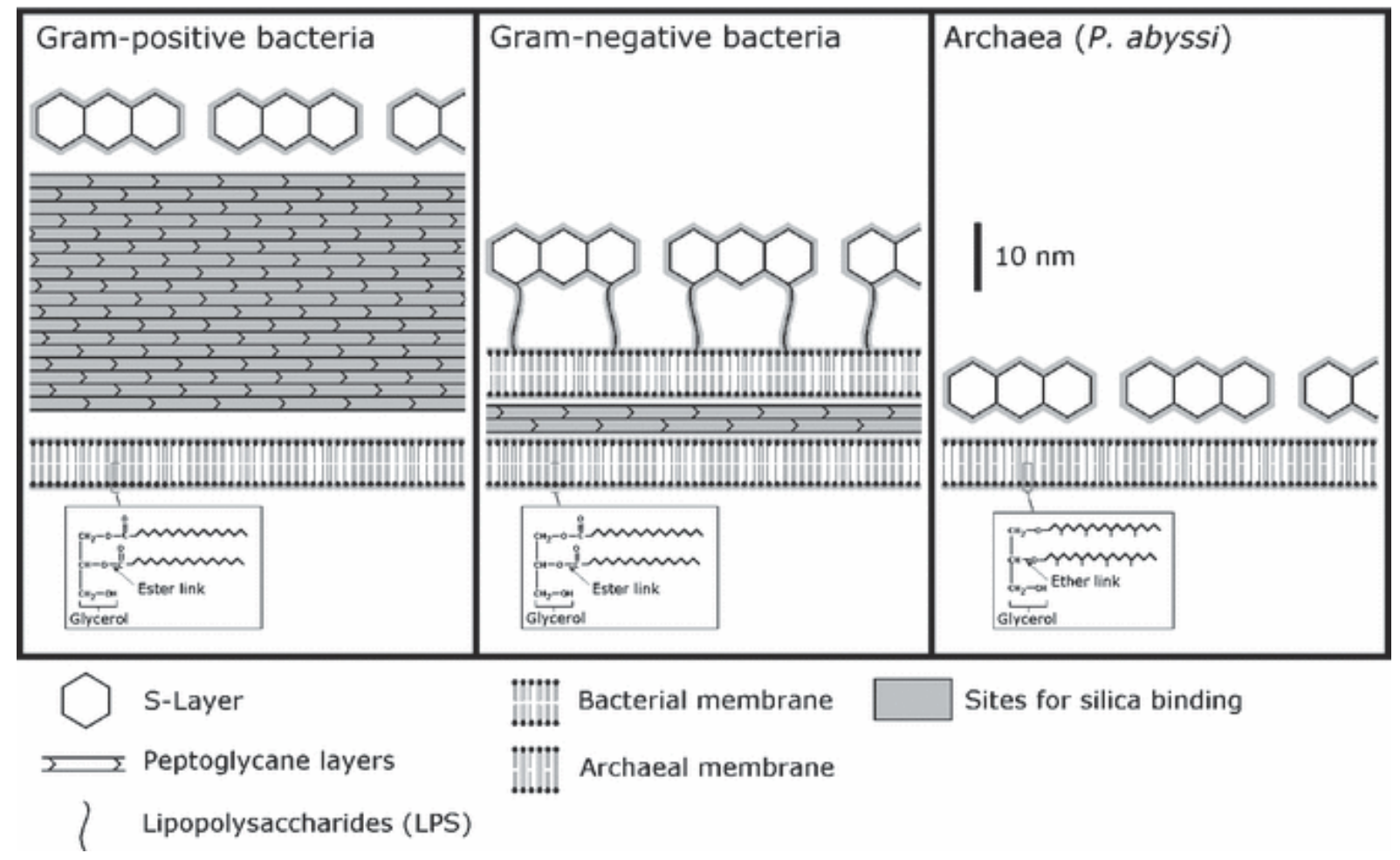

Fig. 9 Schematic representation of the cell-wall structure of the different kinds of prokaryotes (Gram-positive and Gram-negative Bacteria, majority of Archaea). The vertical scale for the different wall components has been respected. Shown in grey tones are the binding sites for silica. Based on data from Sleytr \& Sára (1997), Sleytr \& Beveridge (1999), Beveridge (2001), König (2002) and Patel \& Sprott (2006) for the cell-wall structure, on the review of Konhauser et al. (2004), and our study for the silica-binding sites. 
Table 1 Pyrococcus abyssi silicification experiment

\begin{tabular}{llllll}
\hline Exposure time & Control micrographs & EDX spectra & SEM micrographs & EDX spectra & TEM \\
\hline $0 \mathrm{~h}$ & - & - & Fig. $2 \mathrm{a}$ & - & - \\
$24 \mathrm{~h}$ & - & - & Fig. $2 \mathrm{~b}, \mathrm{c}$ & Fig. 2d & - \\
1 month & Fig. $8 \mathrm{a}$ & Fig. $8 \mathrm{~b}$ & - & - & Figs 2e,f,g and $4 \mathrm{a}$ \\
4 months & - & - & Fig. $3 \mathrm{a}$ & - & Figs $3 \mathrm{~b}$ and $4 \mathrm{~b}$ \\
9 months & - & - & Fig. 3c,d & - & - \\
1 year & - & - & Fig. $3 \mathrm{e}$ & - & Figs $3 \mathrm{f}, \mathrm{g}$ and $4 \mathrm{c}$
\end{tabular}

Summary of all samples and representative images and spectra shown in the figures.

Table 2 Methanocaldococcus jannaschii silicification experiment

\begin{tabular}{llllll}
\hline Exposure time & Control micrographs & EDX spectra & SEM micrographs & EDX spectra & TEM \\
\hline $0 \mathrm{~h}$ & - & - & Fig. $5 \mathrm{a}, \mathrm{b}$ & - & - \\
$24 \mathrm{~h}$ & - & - & Fig. $5 \mathrm{c}$ & Fig. $5 \mathrm{~d}$ & Figs $5 \mathrm{e}-\mathrm{g}$ and $8 \mathrm{e}$ \\
$1 \mathrm{week}$ & - & - & Fig. $5 \mathrm{~h}, \mathrm{i}$ & - & - \\
$1 \mathrm{month}$ & Fig. $8 \mathrm{c}$ & Fig. $8 \mathrm{~d}$ & Fig. 6a & Fig. $6 \mathrm{~b}$ & Fig. $5 \mathrm{j}-1$ \\
1 year & - & - & Fig. $6 \mathrm{c}$ & Fig. $6 \mathrm{~d}$ & Fig. 6e,f \\
\hline
\end{tabular}

Summary of all samples and representative images and spectra shown in the figures.

Table 3 Variations in cell number after exposure to different environmental parameters for 24 h: (1) control sample; (2) silica added to obtain $\left[\mathrm{SiO}_{2}\right]=500 \mathrm{ppm}, \mathrm{pH} \quad 7.5-8.0$; (3) silica added to obtain $\left[\mathrm{SiO}_{2}\right]=500 \mathrm{ppm}$, $\mathrm{pH}$ adjusted to 6.5; (4) $\mathrm{pH}$ increased to $7.5-8.0$

\begin{tabular}{|c|c|c|c|c|c|c|}
\hline & \multicolumn{3}{|c|}{ Growth phase } & \multicolumn{3}{|c|}{ Lysis phase } \\
\hline & $t^{\circ}$ & $t^{\circ}+24 h$ & Evolution (\%) & $t^{\circ}$ & $t^{\circ}+24 h$ & Evolution (\%) \\
\hline 1 & 2.07 & 4.55 & +120 & 4.05 & 2.95 & -27 \\
\hline 2 & 5.12 & 3.55 & -31 & 4.15 & 3.20 & -23 \\
\hline 3 & 4.62 & 3.82 & -39 & 3.62 & 3.15 & -13 \\
\hline 4 & 1.67 & 7.05 & +322 & 2.77 & 1.87 & -33 \\
\hline
\end{tabular}

